\title{
The first complete skeleton of Megaloceros verticornis (Dawkins, 1868) Cervidae, Mammalia, from Bilshausen (Lower Saxony, Germany): description and phylogenetic implications
}

\author{
Thekla Pfeiffer \\ With 5 figures and 4 tables
}

\begin{abstract}
The first well preserved, articulated skeleton of a young male deer of Megaloceros verticornis (Dawkins, 1868) was excavated from early Middle Pleistocene sediments of the clay pit of Bilshausen (Unter-Eichsfeld, Lower Saxony). This find made it possible, for the first time, to establish, using cladistic techniques, the systematic position of Megaloceros verticornis among Pleistocene and Holocene plesiometacarpal and telemetacarpal cervids. By contrast to the antler and tooth characters, the postcranial characters, in particular, are suitable for phylogeny reconstruction. Megaloceros verticornis from Bilshausen shows great similarity with $M$. giganteus of the Upper Pleistocene of Europe in its skeletal morphology, and bootstrap values $(\mathrm{BP}=100)$ show strong support for the monophyly of $M$. giganteus and $M$. verticornis.

The analysis yields no evidence, however, of a close relationship between Dama and Megaloceros, which has been widely discussed in the literature because of the presence of large, palmated antlers in both genera.
\end{abstract}

Key words: Pleistocene, vertebrate palaeontology, cervids, Megaloceros verticornis, skeletal morphology, phylogeny reconstruction, cladistic analysis, taxonomy.

\section{Zusammenfassung}

Aus der Tongrube von Bilshausen (Unter-Eichsfeld, Niedersachsen) konnte das erste, vollständige Skelett eines jungen Hirsches von Megaloceros verticornis (Dawkins, 1868) aus mittelpleistozänen Sedimentablagerungen geborgen werden. Dieser Fund ermöglichte es erstmalig, die systematische Stellung von Megaloceros verticornis im System plesiometacarpaler und telemetacarpaler Hirsche des Pleistozäns und Holozäns auf breiter Basis zu untersuchen. Im Gegensatz zu den Geweih- und Zahnmerkmalen eignen sich die postcranialen Merkmale des Skelettes besonders gut für eine phylogenetische Rekonstruktion der Hirsche.

Die Gemeinsamkeit großer Schaufelgeweihe bei Dama dama und dem Riesenhirsch Megaloceros giganteus hat dazu geführt, beide in eine enge phylogenetische Beziehung zu setzen, was in der Literatur zu einer anhaltenden Kontroverse geführt hat. Die Analyse der Morphologie der postcranialen Elemente zeigt jedoch, dass es keine enge Verwandtschaft zwischen Dama und Megaloceros gibt.

Schlüsselwörter: Pleistozän, Wirbeltierpaläontologie, Cerviden, Megaloceros verticornis, Skelettmorphologie, phylogenetische Rekonstruktion, kladistische Analyse, Taxonomie.

\section{Introduction}

In the early $20^{\text {th }}$ century, Schmidt $(1930,1934)$ recovered a complete skeleton of Alces latifrons from the clay pit of Bilshausen (Lower Saxony, $20 \mathrm{~km}$ SE Göttingen), and several finds of articulated skeletal elements of large mammals were brought to light in the following years. In 1952 the complete extremities of another large cervid were found embedded in the clay, although the body was dislocated and destroyed. Scientific in- vestigations ceased during the second world war, and some material was lost, but fortunately the best preserved find of the early years, the articulated skeleton of $A$. latifrons, was later discovered in the Museum of the Institute for Palaeontology at the University of Göttingen.

This museum also houses the well preserved skeleton of a young male deer of Megaloceros verticornis from Bilshausen (Fig. 1) excavated by D. Meischner and J. Schneider (both at the University of Göttingen) in November 1964

\footnotetext{
1 Gutswiese 21, D-38162 Cremlingen, Germany. Received April, accepted July 2002
} 


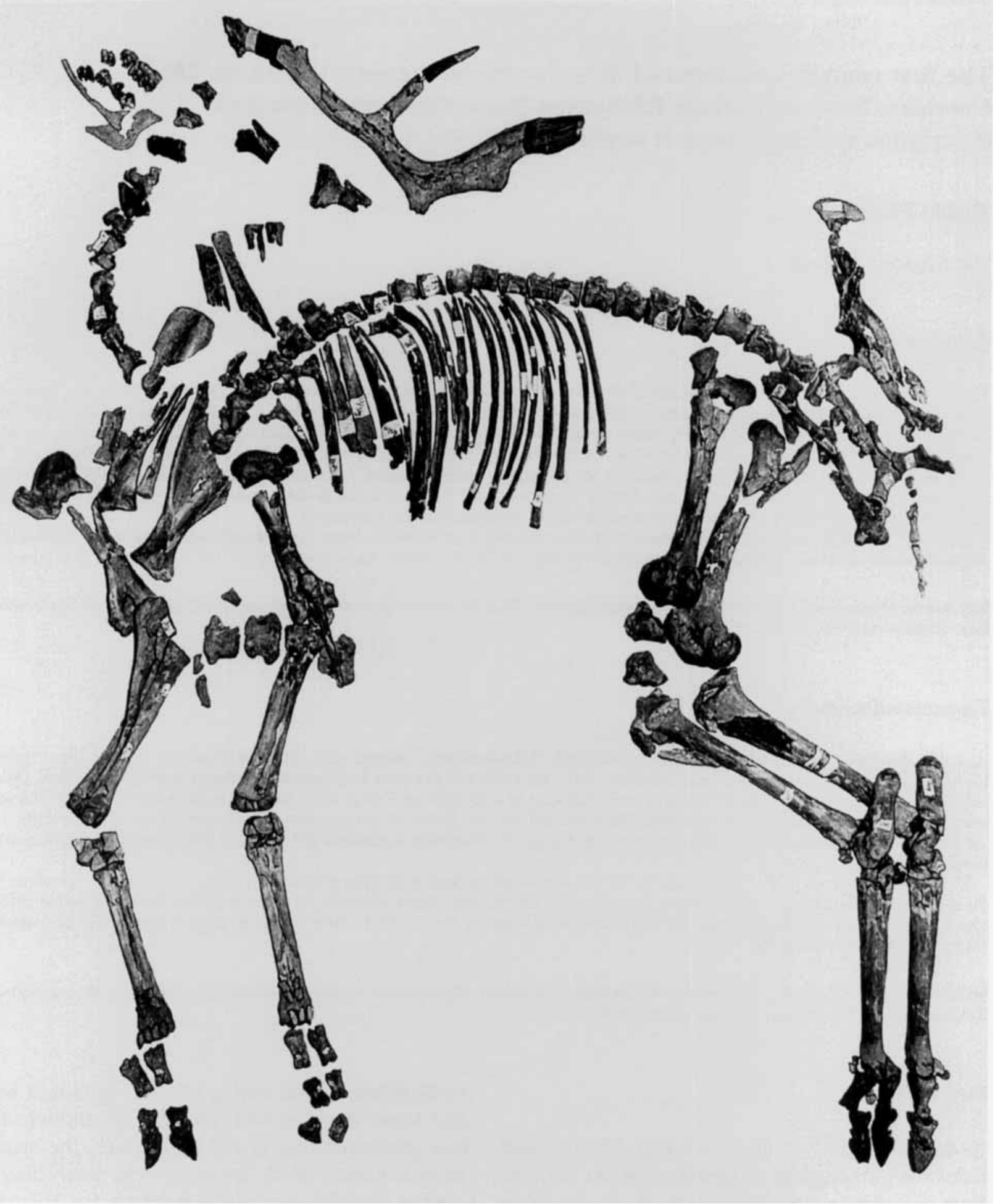

Fig. 1. The first articulated skeleton of a young male of Megaloceros verticornis (Dawkins, 1868) from Bilshausen.

(Meischner \& Schneider 1967). Pollen analysis of the interglacial profile from Bilshausen was carried out by Müller (1965), and Grüger et al. (1994) who made detailed studies of the Middle Pleistocene warm phases of this area. Bittmann \& Müller (1996) correlated the Kärlich Interglacial site with Bilshausen. The age of the
Brockentuff of Kärlich, 396,000 +/-20,000 measured using the ${ }^{40} \mathrm{Ar}{ }^{39} \mathrm{Ar}$ laser method by v. d. Bogaard et al. (1989) was fully compatible with the dating suggested by Bittmann \& Müller (1996) on the basis of the vegetational development. The taphonomy of Bilshausen was interpreted by Meischner (1995) as follows: "Bils- 
hausen was during its existence a meromictic pond ... fishes and mammals abound in the warved black shales. The skeleton of the giant deer showed no remnants of the skin, but the arrangement of the bones indicate that the corpse sank to the bottom, fell on the right side, and came to rest head-down on a slope. Bones maintained their original arrangement, but became disarticulated and were partly rotated, partly pulled-apart, by downslope movement of the still soft sediment." The skeleton of the young male deer of Megaloceros verticornis is especially important because it is the first articulated skeleton found for this species.

Fossil and recent cervids have been described primarily on the basis of antler-, skull- and tooth characters, and additionally on body size. Current morphological taxonomy splits the family Cervidae on the basis of a single character: absence (Hydropotinae) or presence (Odocoileinae + Cervinae) of antlers (Groves \& Grubb 1987), even though the taxonomic value of antlers has been repeatedly questioned (see, for example, Scott \& Janis 1993). Antlers show high variability within a species, and this is dependent on ontogenetic growth patterns and habitat conditions.

Unfortunately, previous workers attempted to ascertain relationships of cervids based only on the comparison of antler and skull characters. An example of this problem is the unresolved discussion concerning the relationships of the Recent fallow deer (Dama dama) and the giant deer (Megaloceros giganteus) which stemms from the beginning of the last century. The presence of large, palmated antlers in Dama dama and Megaloceros giganteus suggested a close relationship between these two taxa (Freudenberg 1914, Geist 1971, 1987, Lister 1984). By contrast Thenius (1958) and Kahlke (1994) held the view that the giant deer must have evolved from deer with antlers that lacked any palmation. Investigations by Pfeiffer (1999a, in press) that also include postcranial characters, show that the genera Megaloceros and Dama belong to clearly separate lineages in the Pleistocene, and that their palmate antlers must have evolved independently.

The systematic position of Megaloceros verticornis has also been controversial (see below). On the basis of the skeleton from Bilshausen, and together with skulls, antlers, and selected postcranial skeletal material from adult individuals of Megaloceros verticornis from the Thuringian localities Süßenborn and Voigtstedt (Kahlke 1956, 1960, 1965, 1969) it is possible to determine the systematic position of this species within the Pleistocene plesiometacarpal deer for the first time. Analysis of the morphology of the postcranial skeletal elements verifies a close relationship between $M$. verticornis and $M$. giganteus.

Gould (1974) showed that the dramatic size reduction of spike antlers in the advanced South American genera Pudu and Mazama suggests that the reversal of morphological trends is possible as a consequence of selection correlated with small body size. Some morphological characters seem therefore to be with highly homoplastic in ungulates (Scott \& Janis 1993), and are difficult to use for determining phylogenetic relationships.

\section{Material}

The analysis conducted here was based on skeletons from males and females of a large number of Recent and fossil deer species, and the skeleton of Megaloceros verticomis from Bilshausen (Table 1). This taxon list includes the Recent telemetacarpal species Alces alces, Rangifer tarandus, Capreolus capreolus, $C$. pygargus, the Middle Pleistocene Roe deer C. suessenbornensis, the Lower Pleistocene plesiometacarpal species Eucladoceros tegulensis, E. dicranios, Dama rhenana, Dama nestii, the Middle Pleistocene Megaloceros verticornis, $M$. giganteus, Cervus elaphus acoronatus, Dama dama clactoniana, D. dama geiselana, and the extant forms Cervus elaphus, $C$. nippon nippon, $C$. nippon hortulorum, Axis axis, D. dama mesopotamica, and D. dama dama. Skeletons of the Recent Moschus moschiferus and skeletal material of the taxa Blastomeryx and Parablastomeryx from the Miocene of North America were added as outgroups.

In addition to skeletons, isolated bones of fossil taxa from different localities were also used. The scapula and pelvis, like the skull, were often broken. In the case of Megaloceros verticornis, the skeleton of the young stag from Bilshausen was analysed together with skulls, antlers and isolated postcranial bones of adult individuals from Süßenborn and Voigtstedt. Because the skull of the deer from Bilshausen is not preserved and this specimen reprents a juvenile, it was necessary to study additional elements from adult individuals.

\section{Method}

A data matrix was coded for the 20 fossil and Recent deer listed above, and the antlerless musk deer, Moschus moschiferus, together with Blastomeryx and Parablastomeryx from the Miocene of North-America were used as outgroups. In current taxonomy, Moschus is commonly accepted as a close relative of the family Cervidae. Blastomeryx and Parablastomeryx share many ancestral features with early cervids including, for example, large upper canines.

The one-hundred and twenty-two morphological characters based on postcranial bones, antlers, skulls, and teeth are explained in Table 2, and listed in the data matrix (Table 3). The characters were coded as "unordered", and equally weighted, while missing data was denoted by a question mark. Polymorphic character states, which occur within a species with approximately the same frequency, were coded with the equate format $a=0+2 ; b=0+1$. Phylogenetic reconstructions were obtained by the maximum parsimony (MP) 
method (PAUP 4.0, Swofford 1998), and the maximum-likelihood (ML) method (quartet puzzling approach: Strimmer \& von Haeseler 1996). The robustness of the phylogeny was assessed using the following approaches: the bootstrap percentage (BT) (Felsenstein 1985) with 1000 resamplings, heuristic search mode; the Jacknife with $50 \%$ deletion, heuristic search mode, 1000 replicates; the reliability percentages (RP), i.e. the number of times the group appears after 10000 ML puzzling steps (Strimmer \& von Haeseler 1996).

\section{Taxonomy}

\section{Megaloceros verticornis (Dawkins, 1868)}

Family Cervidae Goldfuß, 1820

Subfamily Cervinae Goldfuß, 1820

Genus Megaloceros Brookes, 1828

1862 Megaceros Carnutorum - Laugel, A.

1868 Cervus verticornis - Dawkins, $B$.

1869 Cervus (euryceros) Belgrandi - Belgrand, E.

1882 Cervus dawkinsi - Newton, E. T.

1886 Cervus (Dama) priscus - Moullade, E.

1889 Cervus belgrandi - Harmer, F.

1892 Cervus pachygenis - Pomel, A.

1903 Cervus pliotarandoides - de Alessandri, G.

1920 Praemegaceros verticornis - Portis, A.

1927 Cervus megaceros mosbachensis - Soergel, W.

1953 Megaceros verticomis - Azzaroli, A.

1953 'Cervus' obscurus - Azzaroli, A.

1956 Orthogonoceros verticornis - Kahlke, H.-D.

1956 Dolichodoryceros süßenbornensis - Kahlke, H.-D.

1992 Megaceroides verticornis - Azzaroli, A. \& Mazza, P.

1993 Megaloceros verticomis - Lister, A.

The species $M$. verticornis was first described by Dawkins (1868), but initially referred to the genus Cervus.

Laugel (1862) described, with Megaceros carnutorum from St. Prest, the antler characters of Megaloceros verticornis (Pfeiffer 1999b), but figured teeth of Alces. Therefore, Heintz \& Poplin (1981) used carnutorum for an alcine, Alces carnutorum. In any case the cervid material from St. Prest may belong to two or more species. Concerning Praemegaceros, Portis (1920) first used this genus name in connection with the species carnutorum. This cannot be regarded therefore as a valid foundation for Praemegaceros.

Kahlke (1956) referred $M$. verticornis to a new genus, Orthogonoceros, presumed here to be a junior synonym of Megaloceros.

Azzaroli \& Mazza (1992) included Megaloceros verticornis in the genus Megaceroides, which was described by Joleaud (1914) on the basis of a giant deer from Algeria. The antlers of $M$. algericus (Lydekker 1890), the type species of Megaceroides, are poorly known, but the teeth of $M$. algericus, figured by Lydekker (1890) differ in their morphology from those of $M$. verticornis. Consequently, the systematic position of $M$. algericus within the giant deer has yet to be resolved.
Lister (1993, 1994) combined all giant deer species to a single genus Megaloceros following Azzaroli (1953). The name Megaloceros Brookes, 1828 (type species $M$. giganteus) has priority over Megaceros Owen 1842 (Lister 1987, International Commission on Zoological Nomenclature 1989), and the author follows this opinion here.

\section{Description of the skeleton of Megaloceros verticornis from Bilshausen}

\section{Preservation}

This young male individual of $M$. verticornis lay on its right side, legs parallel to one another (Fig. 1). The bones are dark brown, with well preserved surfaces, that usually permit detailed study of the morphological characters. The body is well preserved, but the cervical vertebral column is disarticulated, and the skull, the anterior cervical vertebrae, the main part of the left antler, parts of the lumbar vertebral column, and the sacrum are missing (Fig. 1). Some isolated lower and upper molars are preserved, important among which are the left upper $\mathrm{M}^{3}$ and fragments of the lower $m_{3}$. The last molars are completely developed, but show no $\left(\mathrm{m}_{3}\right)$ or only very little abrasion $\left(\mathrm{M}^{3}\right)$. At the age of 24 months the second dentition is complete in the extant genera Cervus (Habermehl 1961) and Dama (Rieck 1983). If $M$. verticornis developed the last lower and upper molars at the same ontogenetic stage, an age of two years is indicated for this stag at death. This observation is in accordance with several long bones that show incomplete fusion of their epiphyses. The juvenile age also explains the relatively small degree of antler development (Fig. 2) in comparison to adult individuals from Süßenborn (Kahlke 1956, 1969). The right antler is nearly complete, while the left antler is only presented by fragments of the first and second anterior tines.

Both humeri, femora, tibiae, and the metapodials were broken in their proximal part, but are reconstructed. The fragmentary pelvis, sacrum and coccygeal vertebrae were reconstructed, but yield no informative morphological details. All anterior and posterior phalanges are complete and well preserved. As the carpal and tarsal bones were fixed in position during the reconstruction of the skeleton neither measurements, nor morphological details could be collected for these elements. 
Table 1

Skeletal material of the 20 cervid species studied in this investigation.

\section{Recent:}

D. dama dama

D. dama mesopotamica

Axis axis

C. nippon nippon

C. nippon hortulorum

Cervus elaphus

Alces alces

Rangifer tarandus

Capreolus capreolus

Capreolus pygargus

Archaeological sites:

D. dama dama (Kastanas, Demircihüyük)

D. dama mesopotamica (Halawa, Kebara)

Late Pleistocene:

Dama dama (Upper Rhine valley, Lehringen, Trafalgar Square)

Megaloceros giganteus (Upper Rhine valley, Schlutup, Ireland)

Alces alces (Upper Rhine, Valley, Magdeburg-Neustadt)

\section{Middle Pleistocene}

D. dama geiselana (Neumark-Nord)

Cervus elaphus (Neumark-Nord)

D. dama clactoniana (Clacton, Swanscombe,

Jaywick, Grays, Riano, Valdemino, Melpignano)

Cervus elaphus (Clacton, Swanscombe, Jaywick, Grays)

Cervus elaphus acoronatus (Mosbach, Süßenborn, Voigtstedt)

Megaloceros verticornis

(Mosbach, Süßenborn, Voigtstedt, Bilshausen)

Capreolus suessenbornensis (Mosbach, Süßenborn, Miesenheim)

Lower Pleistocene

Dama nestii (Tasso)

Dama rhenana (Senéze, Tegelen)

Eucladoceros tegulensis (Senéze, Tegelen)

Eucladoceros dicranios (Tasso)

The teeth and skeletal elements of Megaloceros verticornis from Bilshausen are relatively large and within the size range of those of Megaloceros verticornis from Süßenborn, and the giant deer, $M$. giganteus, from other Upper Pleistocene German localities (Table 4).

\section{Antler}

The antlers of $M$. verticornis always show a characteristic medially-curved tine at a point 4 to 8 centimetres above the burr, and this can be observed at the antler of the young stag from Bilshausen. In addition, some antlers of $M$. verticornis exhibits a growth near the base of the beam, ranging from a small bump to a strong tine, which is not developed on the antler from Bilshausen. Due to this variation some specimens with a long tine in this position have been separated as species by previous workers, such as Cervus pliotarandoides and 'Cervus obscurus'.

Measures of the preserved right antler are given in Fig. 2. The height of the right pedicle
ㅇ: 28
ㅇ: 12
ㅇ: 10
ㅇ: 11
ㅇ: 6
ㅇ: 10
ㅇ: 7
ㅇ: 4
ㅇ: $8-15$
ㅇ: 1

J/P: 17

का/ㅇ: 6

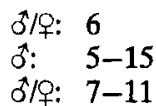

ㅇ: $2-7$

o: 47

१: 15

ठ: 17

ㅇ: 1

की/ 1 : $16-27$

3/9: $2-15$

ơlq: $8-23$

के/?: $2-10$

bิ/9: $4-18$

万ิ/9: 12-29

3: $12-26$

of/o: $12-29$

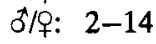

(HRst) is $55 \mathrm{~mm}$, while its diameter (DRst), at $50.5 \mathrm{~mm}$, is quite small. The burr is incomplete, with a preserved diameter (DR) of $56.5 \mathrm{~mm}$, but must have been about $65 \mathrm{~mm}$ in life. These data support a juvenile age. The first anterior tine inserts at a right angle about $60 \mathrm{~mm}$ above the burr. The beam is rounded in its proximal part, with longitudinal ridges on its surface, but without pearls. It becomes flattened in the region where the second anterior tine branches off. A flattened posterior tine, now broken, also branched off $380 \mathrm{~mm}$ above the burr. The distal part of the beam shows a weakly developed palmation and is directed anteriorly. The distal part of the antler is missing, and the preserved length is $747 \mathrm{~mm}$. The beam turns sidewards and upwards above the burr.

\section{Upper molars}

From the right upper jaw a fragment with $\mathbf{M}^{2}$ and $\mathrm{M}^{3}$ is preserved, while from the left side, a fragment of $\mathbf{M}^{1}$, and the complete, isolated $\mathbf{M}^{2}$ 


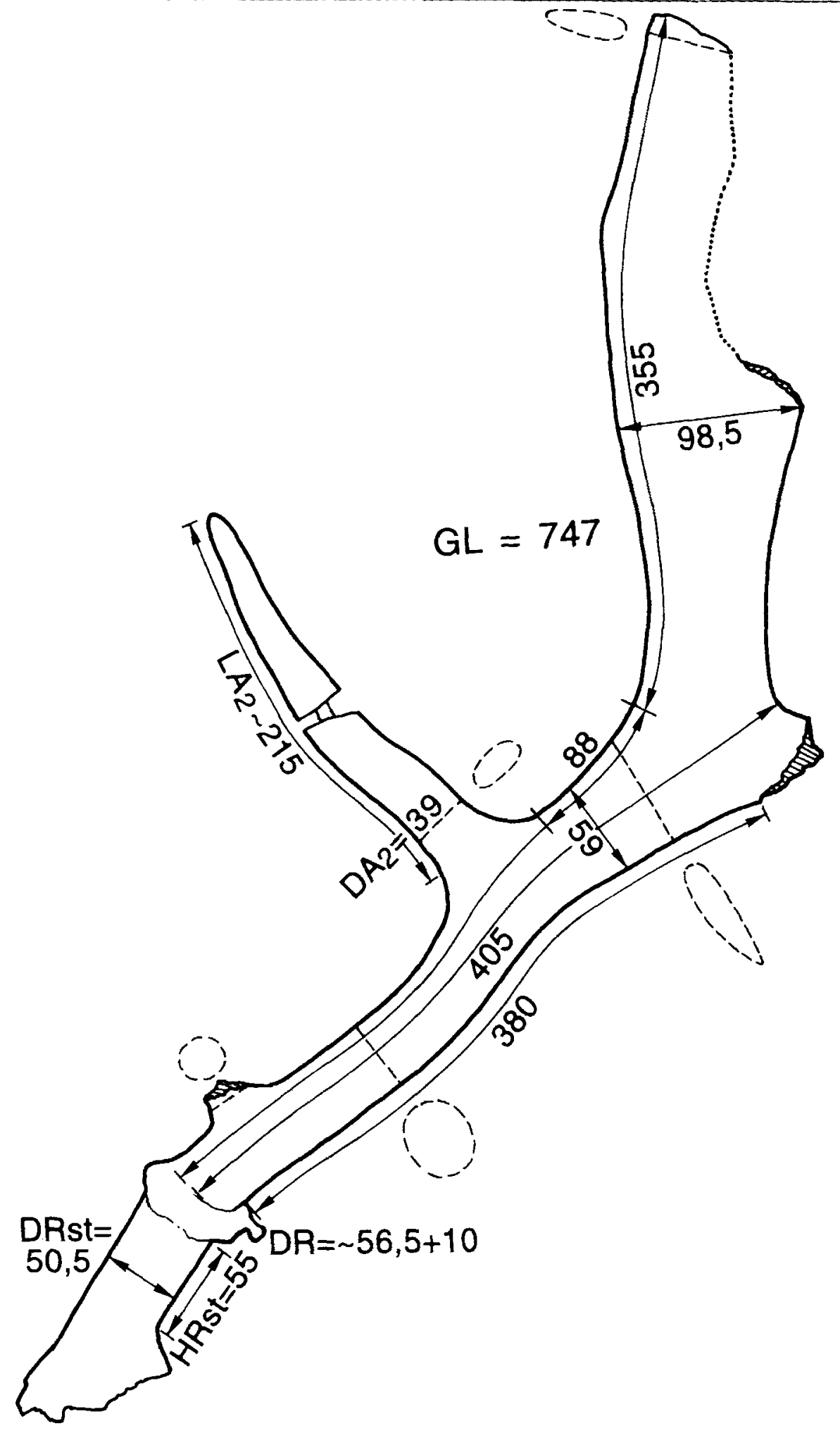

Fig. 2. Right antler of a two year old stag from Bilshausen indicating principal measurements (see explanation in the text). The development of the burr shows that the stag had shed an antler in the year before. The relatively small dimensions confirm a juvenile age. and $\mathrm{M}^{3}$ are measured (Table 4). All molars show well developed entostyli, a small anterior cingulum, and a well expressed posterior cingulum. The anterior and posterior lingual lobes bifurcate posteriorly (Fig. 3a).

\section{Lower molars}

A fragment of the left lower jaw is preserved, but lacks teeth. It is not pachygnathous, as in adult megalocerines, and only slightly thickened. The isolated lower right and left $\mathrm{m}_{1}$, and the left $\mathrm{m}_{2}$ are preserved, the latter showing little abrasion. An anterior cingulum is well developed, and the ectostylid is small (Fig. 3b). Fragments of the lower right and left $\mathrm{m}_{3}$ show no abrasion. This indicates that the individual is of about two years in age. 


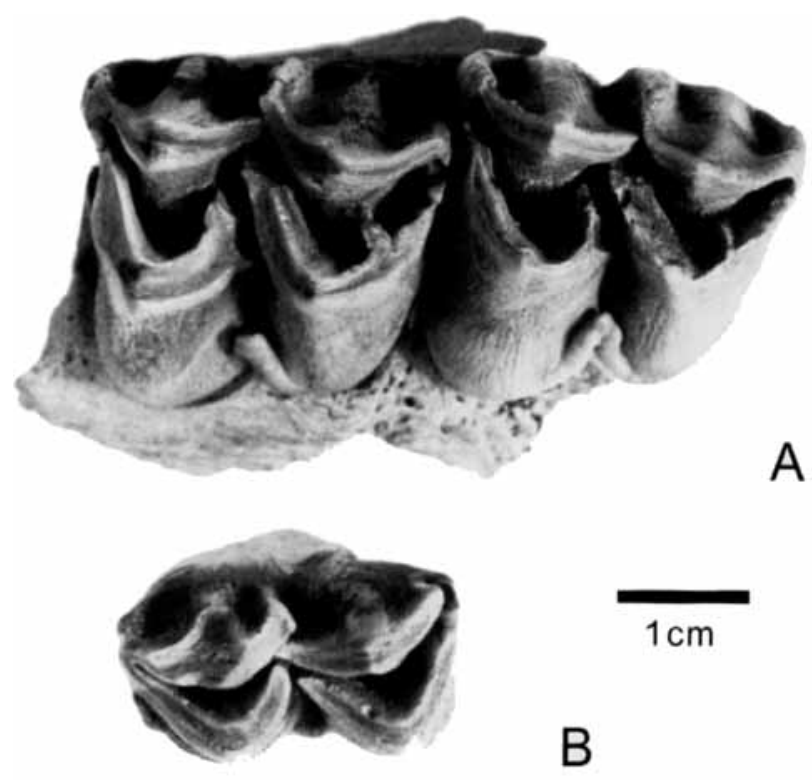

Fig. 3. A. Left upper molars $\left(\mathbf{M}^{2}, \mathbf{M}^{3}\right)$ in occlusal view. $\mathbf{M}^{3}$ shows little abrasion, indicating an individual age of two years at the time of death. All molars show well developed entostyli, a small anterior cingulum, and a well expressed posterior cingulum. The anterior and posterior lingual lobes are bifurcated posteriorly. B. Right lower molar $\left(\mathrm{m}_{1}\right)$ in occlusal view. An anterior cingulum is well developed, the ectostylid is small.

\section{Vertebral column}

Axis: Only the cranial facet of the axis could be measured, its widths is $108.5 \mathrm{~mm}$ (BFcr, v. d. Driesch 1976), and the distal epiphysis is not fused.

Only the corpi of the $3^{\text {rd }}-7^{\text {th }}$ cervical vertebrae are preserved. Each epiphysis is separated from the corpus. Corpus lengths are in the size range typical for Megaloceros. The shape of the cranial epiphyses is similar to those of Megaloceros giganteus, flattened or concave dorsally, wide, and rounded, a diagnostic character for Megaloceros.

The corpus of each thoracic vertebrae is preserved, but not one of the epiphyses is fused. By contrast, the proximal epiphysis of the first lumbar vertebra is fused and shows a weakly depressed margin laterally.

\section{Scapula}

The cavitas glenoidalis is round and wider than long (cha. 12 in the description of character states, Table 2) and it has no V-shaped cavity in its articular surface (cha. 13). the tuberculum supraglenoidale is short, coarse, and not medially curved (cha. 14) as in Megaloceros giganteus. $M$. verticornis has no foramen dorsally between the processus coracoideus and the cavitas glenoidalis (cha. 15) as in most species of deer, while $M$. giganteus has a large foramen in this position. The scapula shaft is robust, but not especially widened as in adult individuals of $M$. giganteus (cha. 17). This character is strongly influenced by antler development. Consequently, the relatively juvenile age and the small antler of the individual from Bilshausen reflect the weaker expression of this feature.

\section{Humerus}

The proximal epiphyses of both humeri are not fused, but the distal epiphyses were just beginning to fuse to the diaphysis at the time of death. Only characters of the distal part could be determined. The fossa radialis shows two rounded scores (cha. 21), a character that is diagnostic for $M$. verticornis and $M$. giganteus. The morphology is generally similar to that of Megaloceros giganteus, except that the epicondylus lateralis has no pronounced bony knob (cha. 22).

\section{Radius and Ulna}

The caput olecrani is not fused to the ulna diaphysis, and the fusion of the distal epiphysis of the radius is incomplete. In addition, there is no bony connection between the diaphyses of the radius and ulna. This is consistent with an ontogenetic stage of two years. The attachment of the ligamentum collateralis laterale at the proximal end of the radius diaphysis projects out laterally, and slopes a little downwards (cha. 26). Megaloceros verticornis from Bilshausen shares this development with Megaloceros giganteus and the genus Cervus. Characters $34-37$ could not be unequivocally assessed because the stag was relatively young.

\section{Metacarpus III + IV}

The epiphyses of the right and left metacarpus III + IV are nearly completely fused. In most species of deer this epiphysis fuses in the end of the second year. The dimensions of these bones are similar to those of Megaloceros giganteus, moreover the specimen of $M$. verticornis from Bilshausen has also stout diaphyses of MC III $+I V$ as is typical for the giant deer. The morphology of the distal end of MC III + IV is generally similar to that of Megaloceros verticornis (cha. 43, 44, 45) and to most plesiometacarpal species of deer.

\section{Pelvis}

The bones of the pelvis are broken into numerous pieces, and no metric data could be obtained. The symphysis pelvina was not fused at the time of death. 


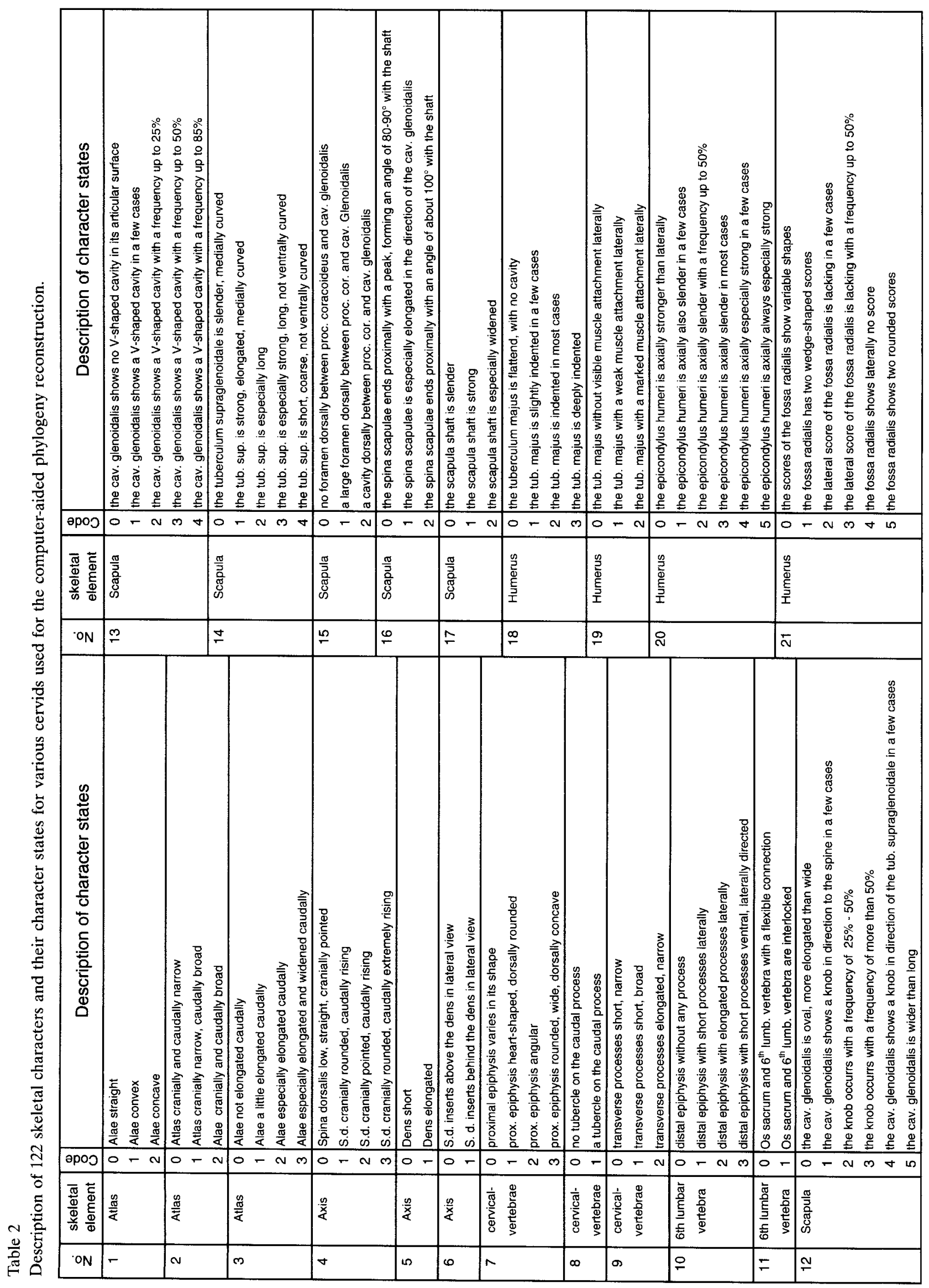




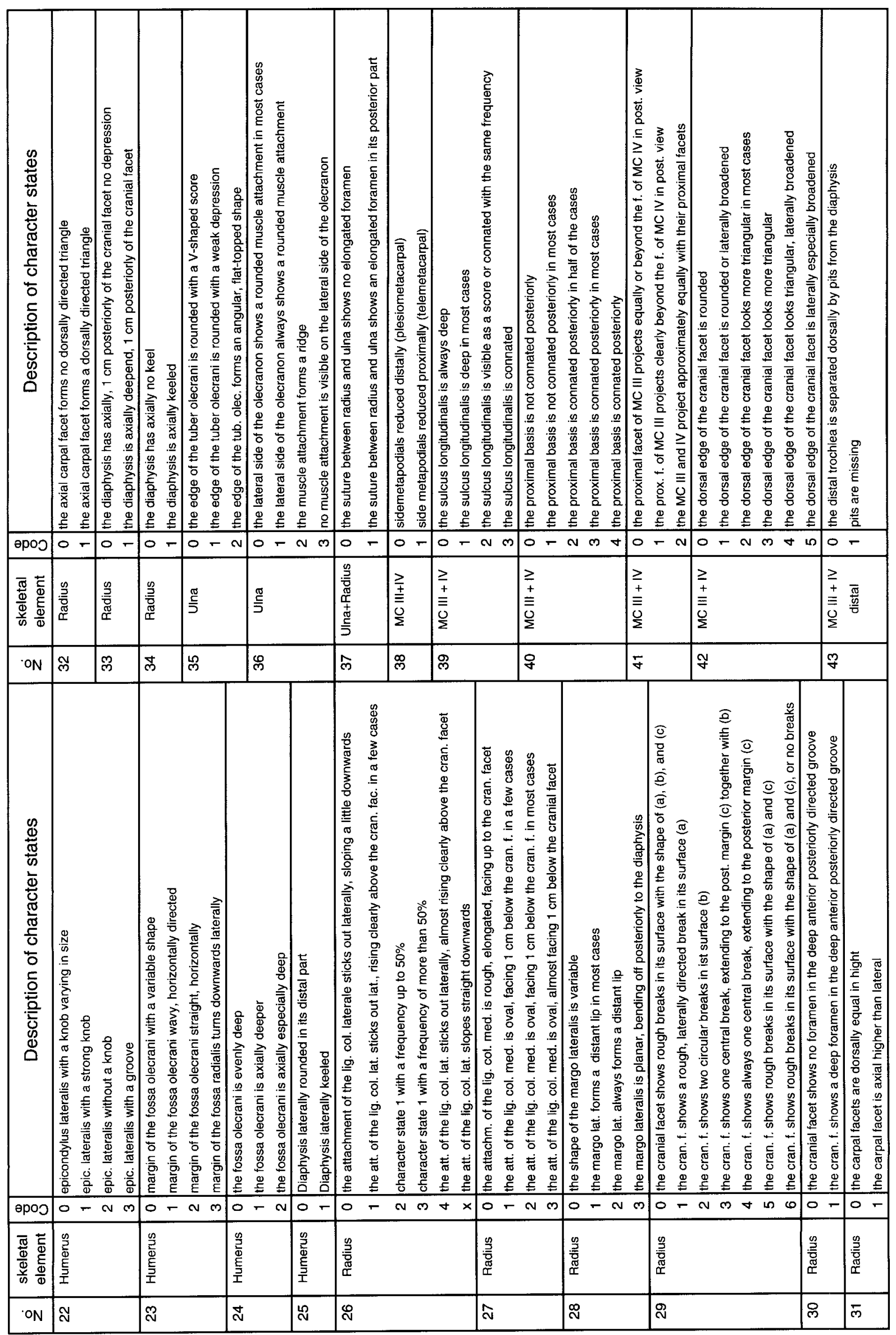




\begin{tabular}{|c|c|c|c|c|c|c|c|c|c|c|c|c|c|c|c|c|}
\hline \multirow[t]{2}{*}{ 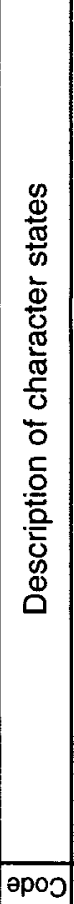 } & \multicolumn{3}{|c|}{ 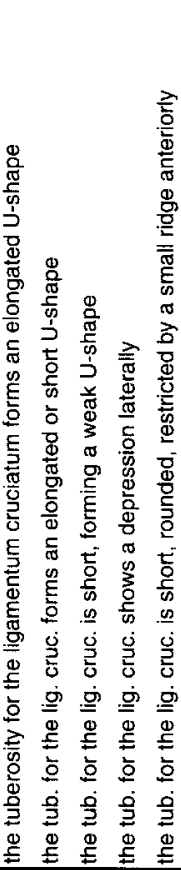 } & 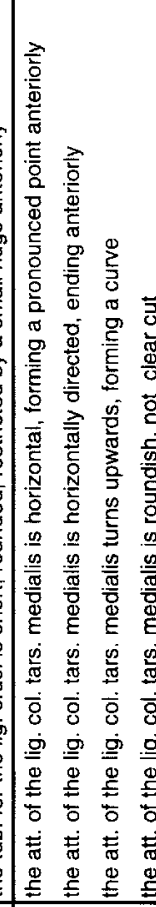 & 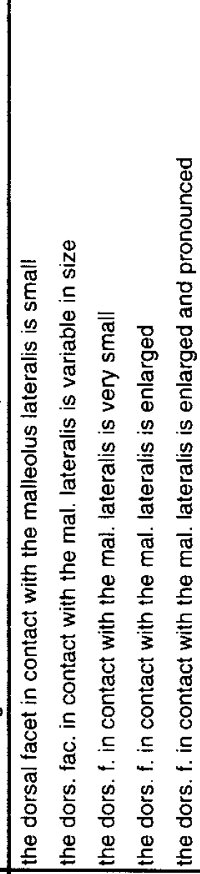 & 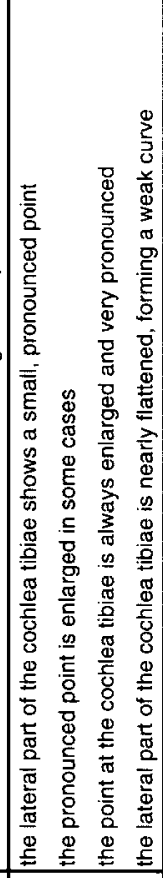 & 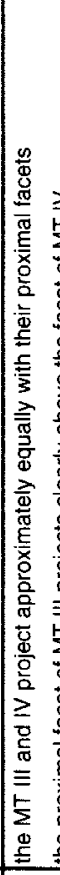 & 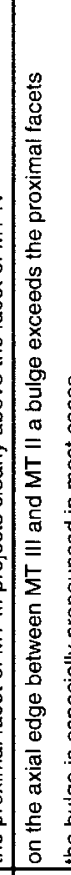 & 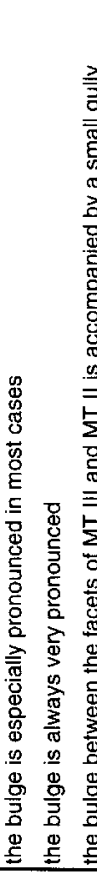 & & 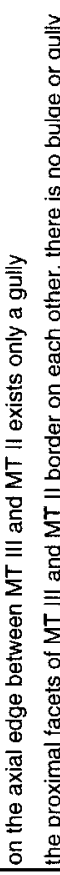 & 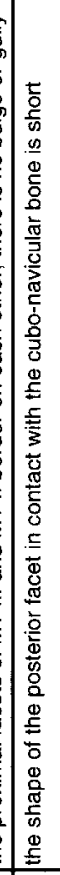 & 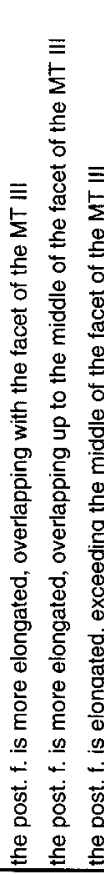 & & 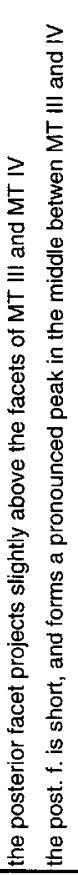 & 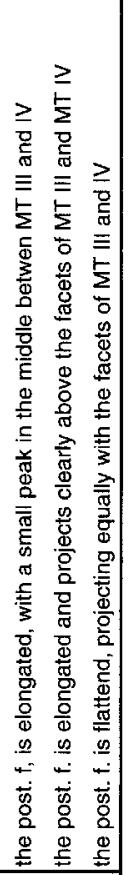 \\
\hline & $0-1$ & $=$ & & $0-\alpha m$ & $0-n d a$ & $0-n m$ & 0 & 它 & $-\alpha m$ & + & in 0 & & $-N m$ & $\nabla$ & $0-$ & Not \\
\hline 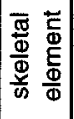 & 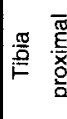 & & & & 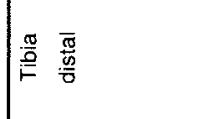 & 总 & & & & & & & & & 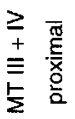 & \\
\hline ON & 吕 & & & 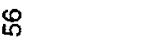 & की & {$\left[\begin{array}{l}\infty \\
i\end{array}\right.$} & : & 8 & & & & $\overline{0}$ & & & 尺ั & \\
\hline 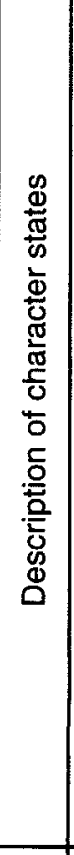 & 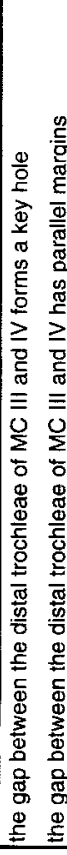 & 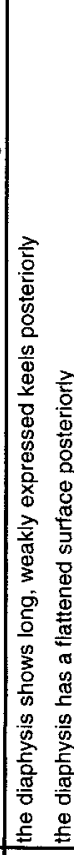 & & 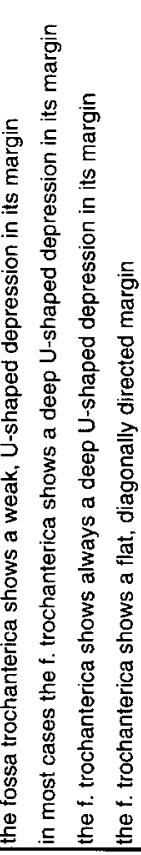 & 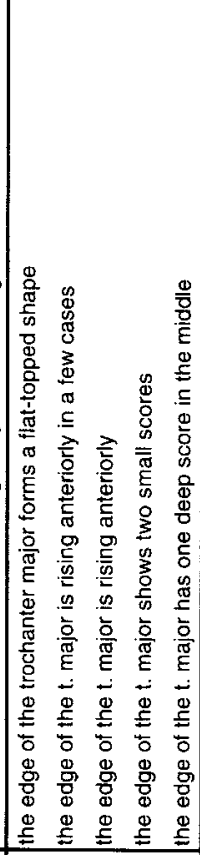 & 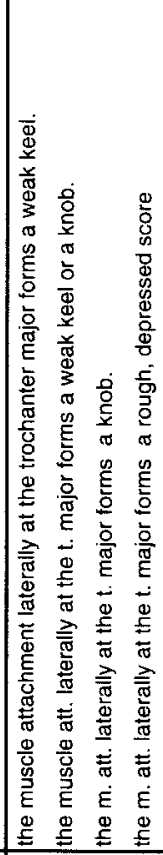 & 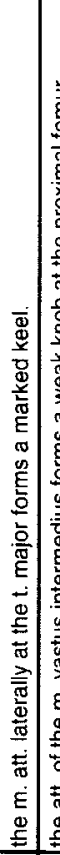 & 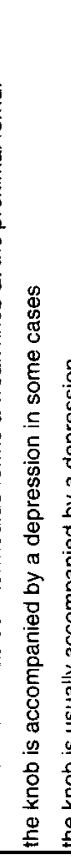 & 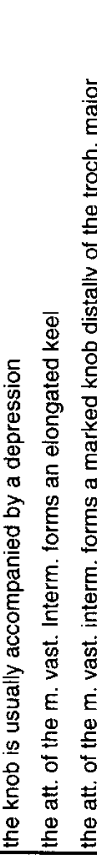 & 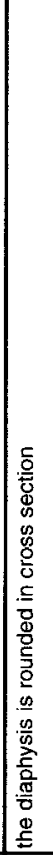 & & 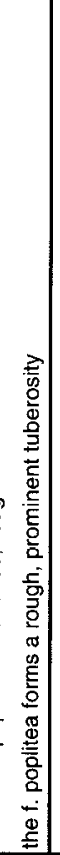 & 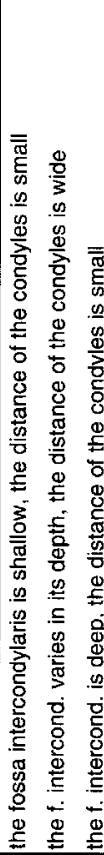 & & 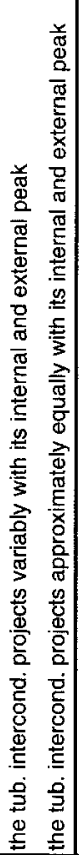 & 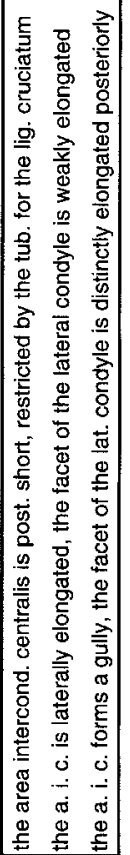 \\
\hline 9000 & $0-$ & $0-$ & & $0-N m$ & $0-2 m$ & $0-2 m$ & + & -8 & $\begin{array}{ll}2 m & m\end{array}$ & & $\begin{array}{l}7 \\
-1\end{array}$ & -7 & $0-n$ & & $\begin{array}{l}=0 \\
-N\end{array}$ & 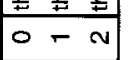 \\
\hline 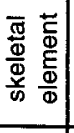 & 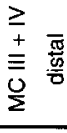 & & & 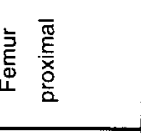 & 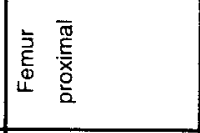 & 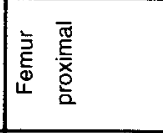 & & & & & & & 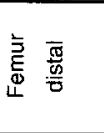 & & & 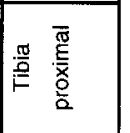 \\
\hline ON & J & \& & & $q$ & 8 & $\stackrel{\alpha}{q}$ & & & & & & & & & & \\
\hline
\end{tabular}




\begin{tabular}{|c|c|c|c|c|c|c|c|c|c|c|c|c|c|c|}
\hline 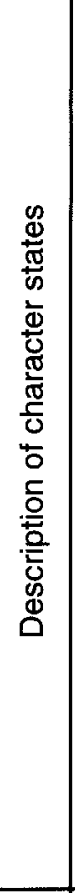 & 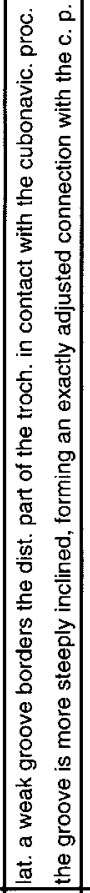 & 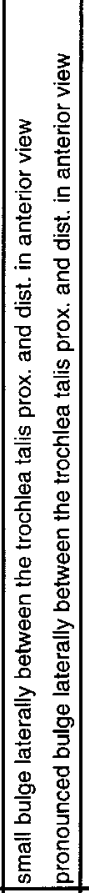 & 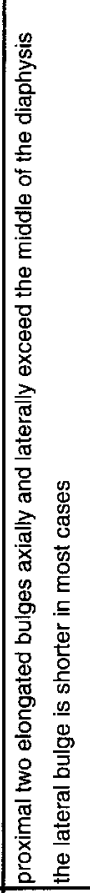 & 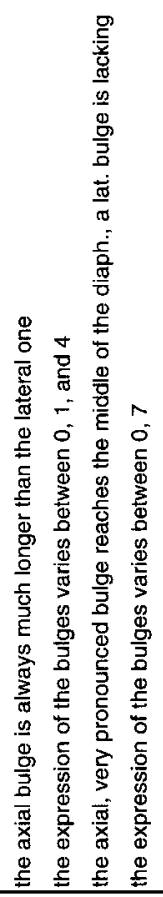 & 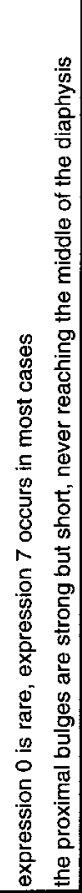 & 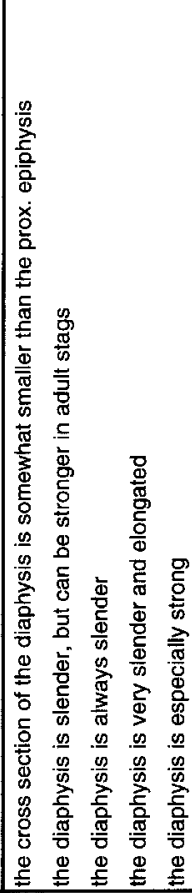 & 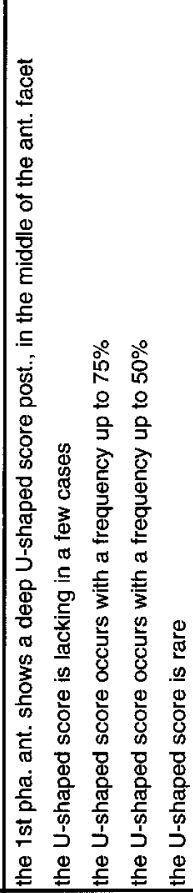 & 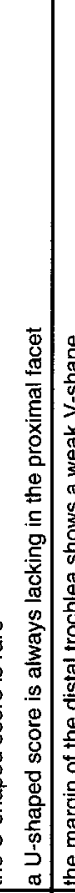 & 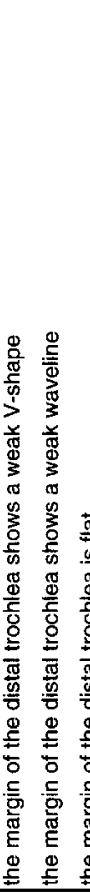 & 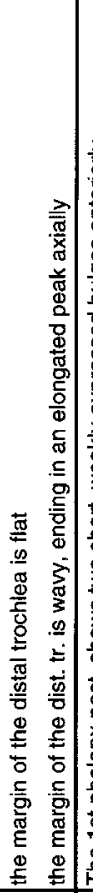 & 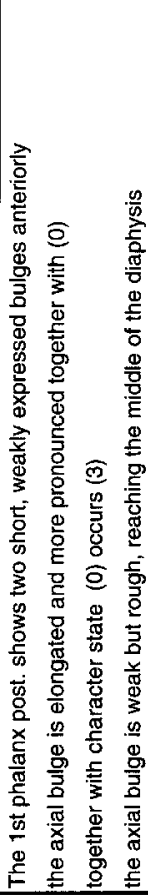 & 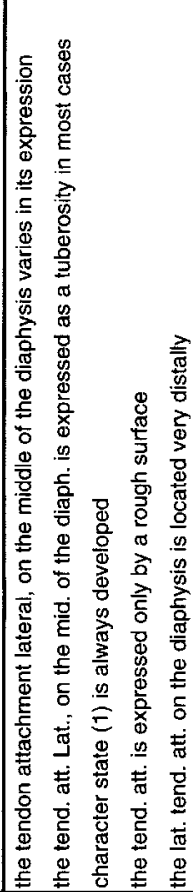 & 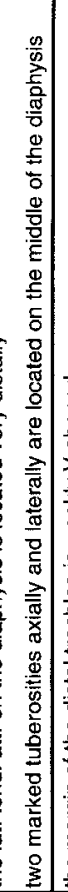 & 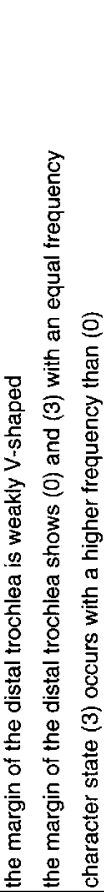 \\
\hline әроO & $0-1$ & $0-1$ & $0-$ & $\sim m+n$ & 01 & $0-\alpha m a$ & $0-\pi m$ & 100 & $0-0$ & त ल & $0-N m$ & $0-n m a$ & in & $0-n$ \\
\hline 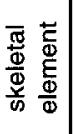 & 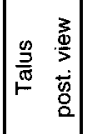 & 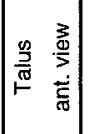 & 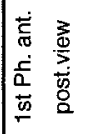 & & & 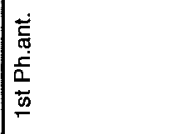 & 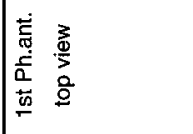 & & 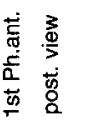 & & 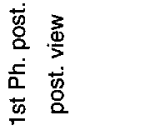 & 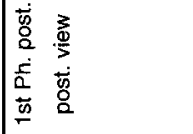 & & 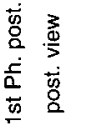 \\
\hline ON & 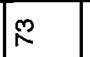 & $\frac{1}{4}$ & R & & & in & N & & $\stackrel{\infty}{\wedge}$ & & $R$ & $\infty$ & & $\bar{\infty}$ \\
\hline 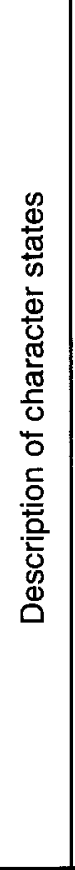 & 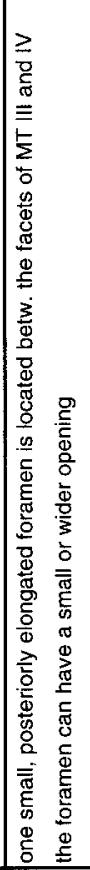 & 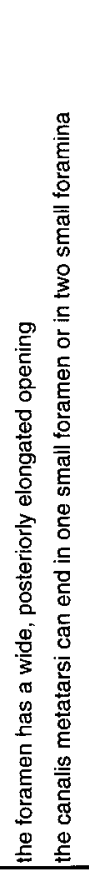 & 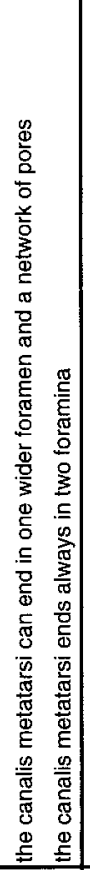 & 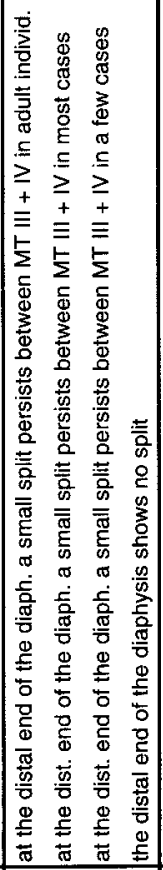 & 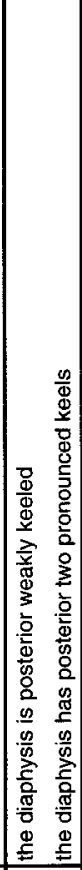 & 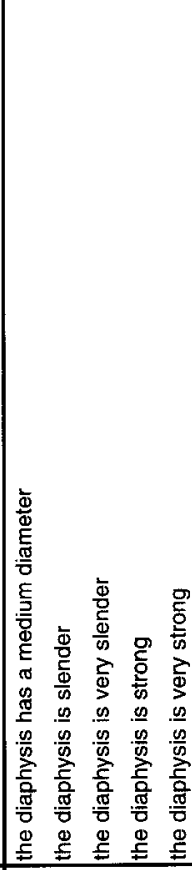 & 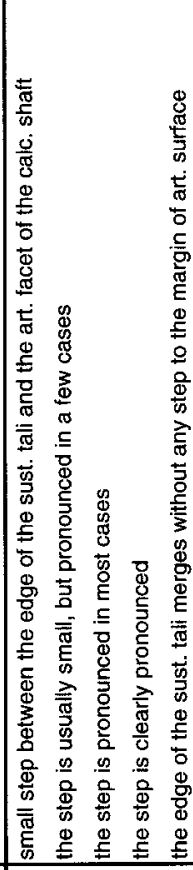 & 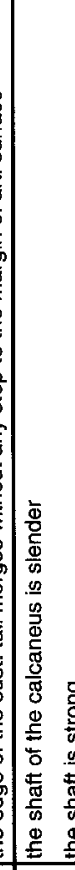 & 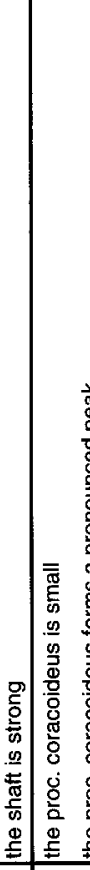 & 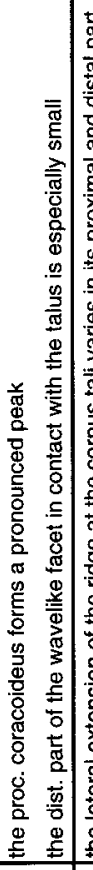 & 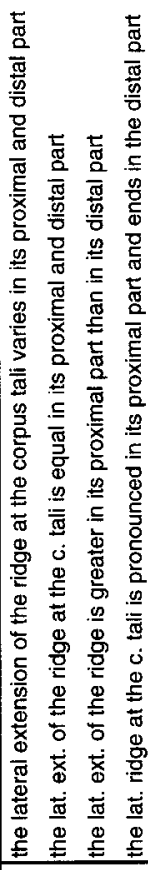 & 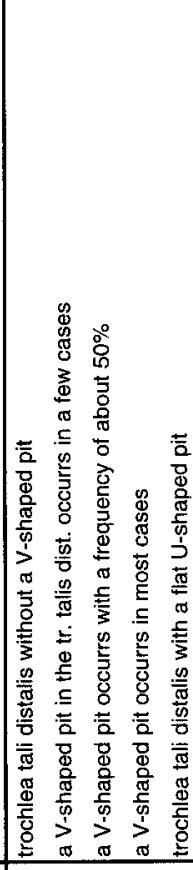 & & 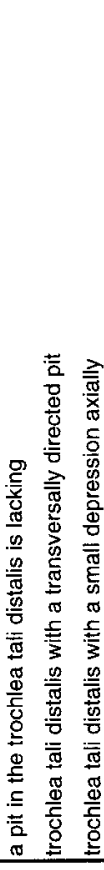 \\
\hline өроэ & $0-$ & Nm & $\Rightarrow$ in & $0-N m$ & $0-$ & $0-n m a$ & $0-n m$ & 10 & -0. & $-\infty$ & $0-N m$ & $0-N m$ & & $-N m$ \\
\hline 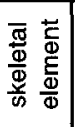 & 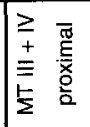 & & & 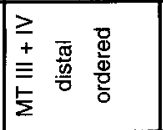 & 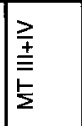 & 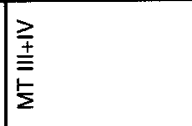 & 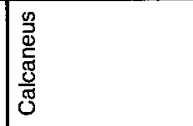 & 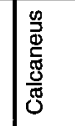 & $\frac{0}{\tilde{\sigma}}$ & & 总产 & 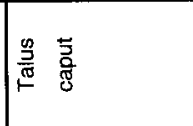 & & \\
\hline ON & 8 & & & \$ & 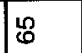 & 8 & $\hat{0}$ & \& & : & & R & $\pi$ & ก & \\
\hline
\end{tabular}




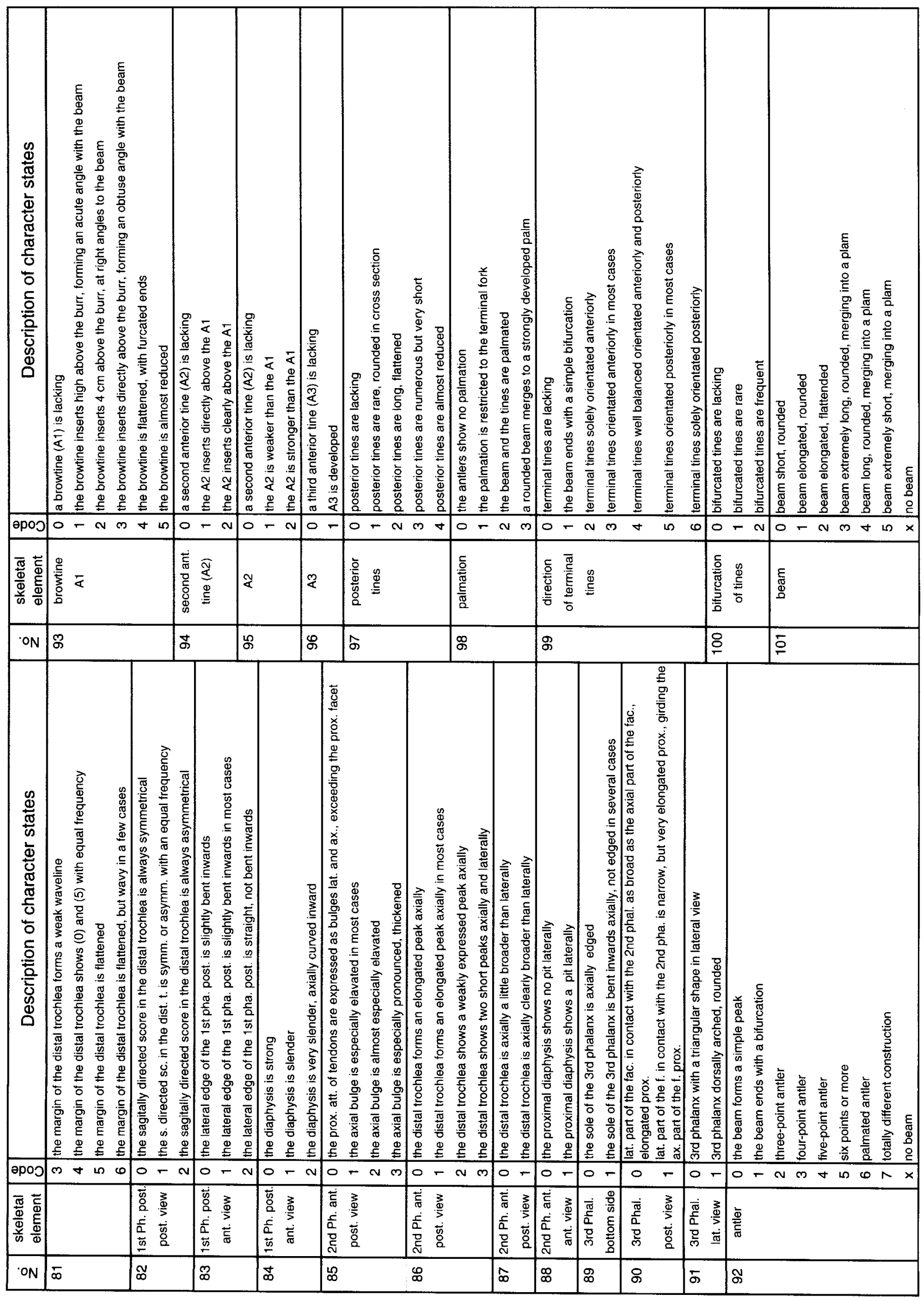




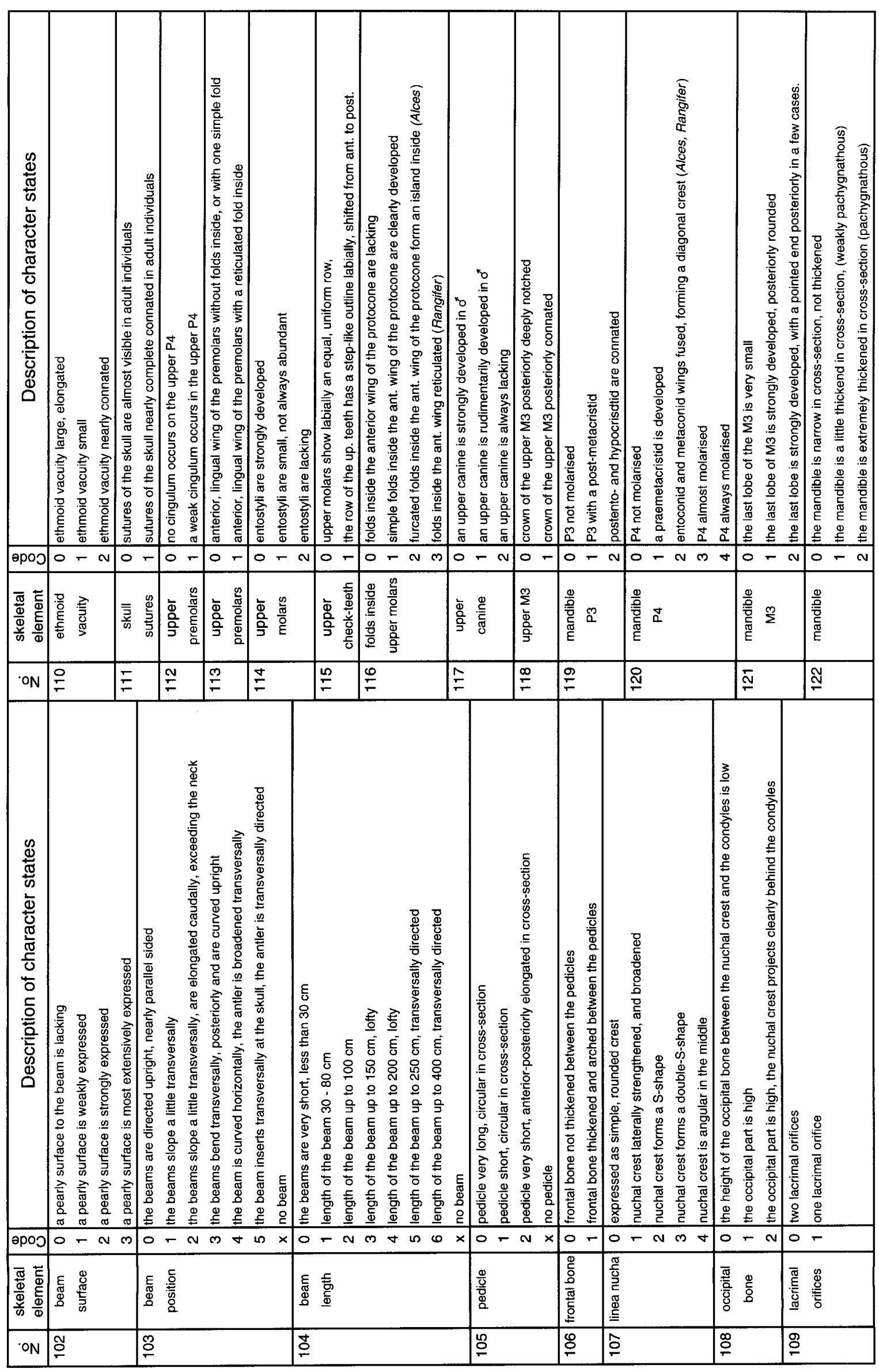


Table 3

Data matrix for 20 selected Pleistocene and Recent cervid species, 3 outgroup artiodactyls, and 122 skeletal characters used in the parsimony analysis (PAUP 4.0).

\begin{tabular}{|c|c|c|c|c|c|c|c|c|c|c|c|c|c|c|c|c|c|c|c|c|c|c|c|c|c|c|c|c|c|c|c|c|c|c|c|c|c|}
\hline \multirow[b]{2}{*}{ Taxa } & \multicolumn{3}{|c|}{ Attas } & \multicolumn{3}{|c|}{ Axis } & \multicolumn{3}{|c|}{ Cerv. } & Lumb & & Scapul & & & & & & imeru & & & & & & & Radius & & & & & & & & Jina & & Metacar & irpus & \\
\hline & 1 & & & & & & 7 & & & & & 121 & & & & & 18 & & & & 22 & & 24 & & $26 \quad 27$ & & 29 & & 313 & 3235 & & & $35 \quad 36$ & & $\begin{array}{ll}38 & 39 \\
\end{array}$ & & \\
\hline Parablastomeryx & $\overline{0}$ & 0 & 1 & 0 & 0 & 0 & 1 & 0 & 0 & 0 & & $0 \quad 0$ & 0 & 50 & $0 \quad 0$ & ? & 1 & 1 & 0 & 2 & 2 & 3 & 0 & 1 & 30 & 3 & 3 & 0 & & & & & 23 & & 92 & 0 & 0 \\
\hline Blastomeryx & 0 & 0 & 1 & 0 & 0 & 0 & $?$ & $?$ & $?$ & 0 & 1 & 0 & & 5 & 0 & 0 & 1 & 2 & 0 & 2 & 2 & 3 & 0 & 1 & 0 & 1 & 1 & 0 & 0 & 1 & & & 3 & 0 & 1 & 0 & \\
\hline Moschus moschiferus & 1 & 0 & 0 & 2 & 0 & 0 & 1 & 3 & 1 & 0 & 1 & 0 & 5 & 5 & 0 & 1 & 0 & 1 & 4 & 2 & 2 & 3 & 0 & & 3 & 1 & 1 & 0 & & & & & 3 & 0 & 1 & 4 & \\
\hline C. suessenbornensis & 0 & 0 & 0 & 0 & 0 & 0 & 3 & 0 & 0 & 0 & 1 & 0 & & & & 0 & 1 & & 0 & & 2 & & 0 & 1 & 0 & 3 & 2 & 0 & 1 & 1 & 1 & & 3 & 0 & 3 & 0 & 0 \\
\hline C.pygargus & 0 & 0 & 0 & 0 & 0 & 0 & 3 & 0 & 0 & 0 & 1 & 0 & 0 & 2 & 0 & 0 & 1 & 2 & 0 & 4 & 2 & 1 & 0 & 1 & 0 & 3 & 2 & 0 & 1 & 1 & 1 & & 3 & 0 & 3 & 0 & \\
\hline C. capreolus & 0 & 0 & 0 & 0 & 0 & 0 & 3 & 0 & 0 & 0 & 1 & 0 & 0 & 2 & 0 & 0 & 1 & 2 & 0 & 4 & 2 & & 0 & & 0 & 3 & 2 & 0 & 1 & 1 & & & 3 & 0 & 1 & 0 & 0 \\
\hline Rangifer tarandus & 1 & 2 & 1 & 3 & 0 & 1 & 3 & 0 & 0 & 0 & 1 & 0 & & 4 & 0 & 1 & 1 & 2 & 0 & 4 & 2 & 2 & 1 & 1 & 0 & 3 & 3 & 0 & 0 & 1 & 0 & 1 & 3 & 0 & 3 & 4 & \\
\hline Alces alces & 0 & 2 & 3 & 2 & 0 & 0 & 3 & 0 & 0 & 0 & 1 & 0 & 0 & 4 & 0 & 1 & 3 & 0 & 0 & 4 & 3 & 1 & 1 & & 0 & 3 & 3 & 1 & 0 & 1 & & & 3 & 0 & 3 & 4 & \\
\hline E. tegulensis & 1 & 1 & 1 & 3 & 1 & 0 & 0 & $?$ & 1 & & 0 & 0 & & 3 & 0 & 0 & 3 & 0 & 0 & 0 & 0 & 0 & 0 & 0 & 0 & 0 & 3 & 0 & 0 & 0 & 0 & 0 & 0 & 0 & 1 & 1 & 0 \\
\hline E. dicranios & 1 & 1 & 1 & 3 & 1 & 0 & 1 & $?$ & 1 & & 0 & $?$ & $?$ & $?$ & $?$ & 0 & ? & $?$ & 0 & 3 & 0 & 0 & 0 & 0 & 0 & 2 & 4 & 0 & 0 & 0 & 0 & & $?$ & & 2 & 2 & \\
\hline Dama menana & 0 & 2 & & 2 & 1 & 0 & 1 & 0 & $\frac{1}{2}$ & 2 & & 0 & & 0 & 0 & 0 & 2 & 0 & 0 & 0 & 0 & 1 & 0 & 0 & 2 & 2 & 0 & 0 & 0 & 0 & 0 & 0 & 1 & 0 & 0 & 1 & 0 \\
\hline Dama nestii & 0 & 2 & 1 & 2 & 1 & 0 & 1 & 0 & 2 & 2 & 0 & 0 & 0 & 0 & 00 & 0 & & 0 & 0 & 0 & 1 & 1 & 0 & 0 & 2 & 1 & 0 & 0 & 0 & 0 & 0 & & & 0 & 3 & 3 & \\
\hline D. dama clactoniana & 0 & 2 & 1 & 2 & 1 & 0 & 1 & 1 & 2 & 2 & & 0 & & 1 & $0 \quad$ & 0 & 3 & 0 & 0 & 1 & 1 & 1 & 0 & 0 & 2 & 2 & 1 & 0 & 0 & 0 & 0 & 0 & 1 & 0 & 0 & 4 & 1 \\
\hline D. dama geiselana & 0 & 2 & 1 & 2 & 1 & 0 & 1 & 0 & 2 & 2 & 0 & 1 & 4 & $a$ & 0 & 0 & & 0 & 1 & 1 & 1 & 0 & 0 & 0 & 2 & 2 & 2 & 0 & 0 & 0 & 0 & & 0 & 0 & 0 & 1 & \\
\hline D. dama dama & 2 & 2 & 1 & 2 & 1 & 0 & 1 & 0 & 2 & 2 & & 2 & 3 & a & 0 & 0 & & 0 & 0 & 1 & 1 & 1 & 0 & 0 & 2 & 2 & 3 & 0 & 0 & 0 & $\underline{0}$ & 0 & 1 & 0 & 3 & 4 & 1 \\
\hline D. dama mesopotamica & 2 & 2 & 2 & 2 & 1 & 0 & 1 & 0 & 2 & 2 & 0 & 3 & 1 & 2 & 0 & 0 & 3 & 0 & 3 & 1 & 1 & 1 & 0 & 0 & 2 & 2 & 3 & 0 & 0 & 0 & 0 & 0 & 2 & 0 & 0 & 4 & \\
\hline Axis sp. (Pirro-Nord) & 1 & 1 & & 1 & 1 & 0 & 1 & 0 & $?$ & 3 & & 0 & 0 & 0 & 0 & 0 & 3 & 0 & 2 & 3 & $t$ & 3 & 0 & 0 & 2 & 2 & 0 & 0 & 0 & 0 & 0 & 0 & $?$ & 0 & 0 & 2 & 1 \\
\hline Axis axis & 1 & $t$ & 2 & 1 & 1 & 0 & 1 & 0 & 0 & 3 & 0 & 4 & 0 & 0 & 0 & 0 & 3 & 0 & 4 & 2 & 2 & 3 & 0 & 0 & 2 & 0 & 1 & 0 & 0 & 0 & 0 & 0 & 3 & 0 & 0 & 4 & \\
\hline Megaloceros verticomis & 0 & 1 & 3 & 3 & 1 & 0 & 3 & $?$ & 1 & & 0 & 5 & 0 & 4 & 0 & $?$ & & 1 & 0 & 5 & 2 & 1 & 2 & & 3 & 3 & 5 & 1 & 0 & 0 & $\underline{0}$ & & 1 & 0 & 0 & 0 & 1 \\
\hline Megaloc & 0 & 1 & 3 & 3 & 1 & 0 & 3 & 1 & 1 & 0 & & 5 & 0 & 4 & 1 & 2 & & 3 & 0 & 5 & 0 & 1 & 2 & 0 & $\times 3$ & 3 & 6 & 1 & 0 & 0 & 0 & 1 & 1 & 1 & 0 & 2 & \\
\hline C. elaphus acoronatus & 1 & 1 & 2 & 3 & 1 & 0 & 2 & 0 & 1 & 0 & 0 & 0 & 0 & 4 & 0 & 0 & & 0 & 5 & 3 & 2 & 3 & 1 & & $\times 0$ & 3 & 5 & 0 & 0 & 0 & 0 & & 1 & & $\underline{0}$ & 0 & 2 \\
\hline C. elaphus hippelaphus & 1 & & 2 & 3 & 1 & 0 & 2 & 0 & & 0 & & 0 & 0 & 4 & & 1 & & 0 & 5 & 3 & 2 & 3 & 1 & & $x$ & 3 & 6 & 0 & $\mathrm{~b}$ & 0 & 0 & 0 & 1 & 0 & 0 & 0 & \\
\hline C. nippon nippon & 1 & 1 & 1 & 1. & 1 & 0 & 2 & 0 & 1 & 0 & 0 & 0 & 0 & 0 & 0 & 0 & & 0 & 5 & 3 & 2 & 3 & 0 & & $\mathrm{x}$ & 3 & 5 & 0 & 0 & 0 & 0 & 0 & 13 & & 0 & 4 & 2 \\
\hline C. nippon hortulorum & 2 & 1 & 2 & 1 & 1 & & 2 & 0 & & 0 & & 0 & 0 & $\underline{2}$ & 0 & 0 & & 0 & 5 & 3 & 2 & 3 & 0 & 0 & $x$ & 3 & 5 & 0 & 0 & 0 & 0 & 0 & 13 & 0 & & 4 & 2 \\
\hline & & & & & Fen & ner & & & & & & Tibia & & & & & & etatar & isus & & & & & & Calcan & & Astr & ragal & & & & 1st $P$ & Pha. an & & 1st Pha & ha. po & \\
\hline & 42 & 43 & 44 & 45 & 46 & 47 & 48 & 49 & 50 & 51 & 52 & 535 & 54 & 55 & 565 & 5758 & & 960 & 61 & 62 & 63 & 64 & & 66 & & & 70 & 71 & 727 & 737 & & & 7677 & & & 081 & 82 \\
\hline Parablastomeryx & 6 & 1 & 0 & 0 & 2 & & 4 & 3 & 0 & 1 & 1 & 2 & 0 & 2 & 2 & 40 & & 6 & 0 & 1 & 4 & 0 & 1 & 2 & $0 \quad 0$ & 0 & 1 & 0 & 1 & 1 & & ? & $3 ?$ & 0 & 3 & & \\
\hline Blastomenx & 6 & 2 & 0 & 0 & 2 & 4 & 4 & 3 & 0 & 1 & & & 0 & 1 & 2 & 0 & & 5 & 0 & 1 & 0 & & & & 0 & 0 & 1 & 0 & 1 & 1 & & & 3 & & 3 & 0 & \\
\hline Moschus moschiferus & 6 & 1 & 1 & 0 & 2 & 4 & 4 & 3 & o & 0 & & 2 & 0 & 2 & 2 & 4 & & 6 & 0 & 0 & 2 & 0 & 1 & & 4 & 2 & 1 & 0 & 1 & b. & & 8 & 0 & 2 & 3 & 1 & \\
\hline C. sue & 3 & 0 & 0 & 0 & 1 & 0 & 0 & 0 & 1 & 1 & & 0 & 1 & 2 & 0 & 0 & & 6 & 1 & 0 & 1 & 0 & 0 & & 0 & 0 & 1 & 0 & 0 & 0 & & & 3 & 3 & 0 & 2 & 2 \\
\hline C.pygargus & 3 & 0 & 0 & 0 & 1 & 0 & 0 & 0 & 1 & 1 & 1 & 0 & $i$ & 2 & 0 & 0 & & 6 & 1 & 0 & 1 & 0 & 0 & & 0 & 0 & 1 & 0 & 0 & 0 & & 7 & 3 & 3 & 0 & 2 & \\
\hline c. cat & 3 & 0 & 0 & 0 & 1 & 0 & 0 & 0 & 1 & 1 & & 0 & 1 & 2 & & & & 6 & 1 & 0 & 1 & 0 & 0 & & 0 & 0 & $i$ & 0 & 0 & 0 & & 7 & 3 & & 0 & 2 & 2 \\
\hline Rangifer tarandus & 3 & 0 & 0 & 2 & 3 & 4 & 4 & 4 & 0 & 0 & & 2 & 0 & 2 & 4 & 0 & & 3 & 0 & 0 & 4 & 3 & 1 & 0 & 0 & 2 & 1 & 0 & 2 & 0 & & 7 & 0 & 2 & 0 & 3 & 2 \\
\hline Aices & 3 & 0 & 0 & 0 & 3 & 4 & 4 & 4 & 0 & 0 & 0 & 0 & 1 & 2 & 3 & 0 & & 6 & 2 & 3 & 4 & 0 & & & 0 & 1 & 1 & 0 & 0 & 0 & & 7 & 0 & & 0 & 3 & 2 \\
\hline E. tegulensis & 2 & 1 & 1 & 0 & 1 & 0 & 0 & 2 & 0 & 0 & & 1 & 0 & 0 & 0 & 1 & & 0 & 0 & 0 & 1 & 0 & & 3 & 0 & 0 & 0 & 0 & 1 & 0 & & 6 & 4 & 2 & 1 & 6 & 0 \\
\hline E. dicranios & 1 & 1 & 1 & 0 & $?$ & $?$ & $?$ & $?$ & 0 & 0 & & $?$ & 0 & $?$ & 0 & 0 & & 2 & 0 & 0 & 0 & 0 & & 3 & 0 & 0 & 0 & 1 & 1 & 0 & & 7 & 0 & & 1 & 5 & \\
\hline Oama & 2 & & 1 & & 3 & 0 & 1 & 0 & 0 & 0 & 2 & 0 & 0 & 0 & 0 & 0 & & 1 & 2 & 2 & 2 & 1 & & & $\frac{0}{1}$ & 1 & 1 & 2 & 1 & 0 & & 1 & 2 & 0 & 0 & 1 & 2 \\
\hline Dama nestii & 2 & 1 & 1 & 0 & 3 & $?$ & ? & $?$ & 0 & 0 & 2 & 0 & 0 & 2 & 0 & 0 & & 2 & 2 & 2 & 3 & 1 & 0 & 0 & 3 & 0 & 1 & 2 & 1 & 0 & & 1 & 1 & $b$ & 0 & 1 & \\
\hline D. dama clactoniana & 3 & 1 & 1. & 0 & 3 & 1 & 2 & 0 & 0 & 0 & & 1 & 0 & 2 & 0 & 3 & & $\frac{\pi}{2}$ & 2 & 2 & 3 & 2 & & 0 & 3 & 0 & 1 & 1 & 1 & 0 & & & 2 & & 2 & 2 & \\
\hline D. dan & 3 & 1 & 1 & 0 & 3 & 1 & 2 & 1 & 0 & 0 & 2 & 0 & 0 & 2 & 0 & 4 & & 2 & 3 & 2 & 3 & 2 & 0 & 0 & 2 & 0 & 1 & 3 & 1 & 0 & & 2 & 4 & 1 & 0 & & \\
\hline D. da & 5 & 1 & 1 & & 3 & 1 & 2 & 1 & 0 & 0 & & 1 & 0 & 2 & 0 & 4 & & 2 & 3 & 2 & 5 & 2 & 0 & & 2 & 0 & 1 & 1 & 1. & 0 & & 2 & 4 & 1 & 0 & & \\
\hline nesopotamica & 5 & 1 & 1 & 1 & 3 & 2 & 3 & 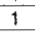 & 0 & 0 & & 0 & 0 & 2 & 1 & 3 & & 2 & 3 & 2 & 4 & 3 & 0 & 0 & 3 & 0 & 1 & 1 & 1 & 0 & 0 & 2 & 2 & 1 & 0 & 3 & 2 \\
\hline (Pirro-Nord) & 2 & 1 & 1 & 0 & 0 & 3 & & 3 & 0 & 0 & & 0 & 1 & 3 & $?$ & 0 & & 3 & 3 & 0 & 0 & 0 & 0 & 1 & 0 & 0 & 1 & 0 & 1 & 0 & & 3 & 3 & & 0 & & \\
\hline Axis a & 3 & 1 & 1 & 1 & 0 & 3 & 4 & 3 & 0 & 0 & 0 & 0 & 1 & 3 & 2 & 0 & 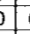 & 4 & 3 & 0 & 0 & 0 & 0 & 0 & 4 & 0 & 1 & 0 & 1 & 0 & 0 & 4 & 4 & 2 & 2 & 2 & \\
\hline Megaloceros verticomis & 0 & 1 & 1 & 0 & 3 & 0 & 0 & 0 & 0 & 0 & & 0 & 2 & 0 & 3 & 2 & & 0 & 1 & 1 & 0 & 0. & 0 & & 0 & 0 & 0 & 0 & 3 & 1 & & 1 & 0 & & 0 & & \\
\hline Mega & 0 & 1 & 1 & 0 & 1 & 0 & 4 & 3 & 1 & 0 & 1 & 0 & 2 & 1 & 3 & 3 & & 0 & 1 & 1 & 0 & 0 & 0 & 4 & 0 & 0 & 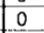 & 0 & 3 & 1 & 0 & 1 & 4 & 2 & 0 & 5 & \\
\hline C. elaphus acoro & 0 & 1 & 1 & 0 & 1 & 0 & 0 & 0 & 0 & 0 & & 0 & 0 & 0 & 1 & 2 & & 5 & 3 & 0 & 2 & 0 & 0 & & 4 & 0 & 2 & 0 & 0 & 0 & & 5 & 4 & 2 & 0 & 3 & \\
\hline C. elaphus hippelaphus & 3 & 1 & 1 & 0 & 1 & 0 & 0 & 0 & 0 & 0 & & 0 & 0 & 4 & 1 & 2 & & 5 & 3 & 0 & 2 & 0 & 0 & 3 & 4 & 0 & 3 & 0 & 0 & 0 & & 6 & 4 & 2 & 0 & 5 & \\
\hline C. nippon nippon & 0 & 1 & 1 & 0 & 0 & 0 & 0 & 0 & 0 & 0 & & 0 & 0 & 4 & & & & 5 & 4 & 4 & 2 & 0 & 0 & & 4 & 0 & 3 & 1 & 0 & 0 & & 7 & 4 & 0 & 3 & 4 & \\
\hline C. nippon hortulorum & 4 & 1 & 1 & 0 & 0 & 0 & 0 & 0 & 0 & 0 & 1 & 0 & 0 & 4 & 1 & 1 & & 5 & 4 & 4 & 2 & 0 & 0 & 0 & 0 & 10 & 0 & 1 & 0 & 0 & & 7 & & & 33 & 4 & \\
\hline
\end{tabular}

\begin{tabular}{|c|c|c|c|c|c|c|c|c|c|c|c|c|c|c|c|c|c|c|c|c|c|c|c|c|c|c|c|c|c|c|c|c|c|c|c|c|c|c|c|c|}
\hline \multirow{3}{*}{ Taxa } & \multirow{2}{*}{\multicolumn{2}{|c|}{8384}} & \multicolumn{4}{|c|}{ 2nd Pha. ant. } & \multicolumn{3}{|c|}{ 3rd Pha. } & \multicolumn{13}{|c|}{ Antler } & \multicolumn{7}{|c|}{ Skull } & \multicolumn{7}{|c|}{ Maxilla } & \multicolumn{4}{|c|}{ Mandibula } \\
\hline & & & 85 & 86 & 87 & 88 & 89 & 90 & 91 & 92 & & 94 & 95 & 96 & 97 & 98 & & & & 02.1 & & $104 \mid 1$ & & & & 108 & 109 & & & 112 & & 114 & & 116 & & 118 & & & & \\
\hline & & & 2 & 1 & 0 & 0 & 0 & 0 & 0 & $x$ & 0 & 0 & 0 & 0 & 0 & 0 & 0 & & $x$ & $\underline{0}$ & $x$ & $x$ & $\mathrm{x}$ & 0 & 0 & 0 & 1 & 0 & 0 & 0 & 0 & 1 & 0 & 0 & & 0 & 0 & 0 & & 0 \\
\hline Blastomeryx & & 4 & 2 & 1 & 0 & 0 & 0 & 1 & 0 & $x$ & 0 & 0 & 0 & 0 & 0 & 0 & 0 & $\begin{array}{l}0 \\
\end{array}$ & $\bar{x}$ & 0 & $x$ & $x$ & $x$ & 0 & 0 & 0 & 1 & 0 & 0 & 0 & 0 & 2 & 0 & 0 & 0 & 0 & 0 & 0 & 1 & 0 \\
\hline Moschus moschiferus & & & 3 & 1 & 0 & 0 & 0 & 0 & 0 & $x$ & 0 & 0 & 0 & 0 & 0 & 0 & 0 & 0 & $\bar{x}$ & 0 & $x$ & $x$ & $\bar{x}$ & 0 & 0 & 0 & 1 & 0 & 0 & & & 2 & 2 & 1 & & 1 & & & & \\
\hline C. suessenbormensis & & 2 & 0 & 0 & 0 & 0 & 0 & 0 & 0 & 2 & 0 & 0 & 0 & 0 & 1 & 0 & 1 & 0 & 2 & 3 & 0 & 0 & 0 & 0 & 0 & 0 & 0 & $?$ & 0 & 0 & 0 & 1 & 0 & 1 & 2 & 1 & 0 & $t$ & 0 & 1 \\
\hline $\begin{array}{l}\text { C.pygargus } \\
\end{array}$ & & 2 & 0 & 0 & 0 & 0 & 0 & 0 & 0 & 1 & 0 & 0 & 0 & 0 & 1 & 0 & 1 & 0 & 2 & 3 & 0 & 0 & 0 & 0 & 0 & 0 & 0 & 0 & 0 & 0 & $\underline{a}$ & 1 & 0 & 1 & 2 & 1 & & 1 & 0 & 1 \\
\hline C. capreolus & & 2 & 0 & 0 & 0 & 0 & 0 & 0 & 0 & 1 & 0 & 0 & 0 & 0 & 1 & 0 & 1 & 0 & 0 & 3 & 0 & 0 & 0 & 0 & 0 & 0 & 0 & 0 & 0 & 0 & 0 & 1 & 0 & 1 & 2 & 1 & 0 & 1 & 0 & 1 \\
\hline Rangifer tarandus & & 0 & 3 & 2 & 1 & 0 & 0 & 1 & 1 & 6 & 4 & 0 & 0 & 0 & 2 & 3 & 6 & 2 & 2 & 0 & 2 & 3 & 1 & 0 & 1 & 0 & 0 & 0 & 0 & 1 & 0 & 2 & & 3 & 1. & 1 & & 2 & 0 & \\
\hline Alces alces & 2 & 0 & 3 & 2 & 1 & 0 & 0 & 1 & 0 & 6 & & 0 & 0 & 0 & 2 & 3 & 3 & & 5 & 0 & 5 & 5 & 1 & 1 & 4 & 2 & 0 & 0 & 0 & 0 & 0 & 1 & & 2 & & & & 2 & 0 & 1 \\
\hline E. tegulensis & 0 & 0 & 3 & 1 & 0 & 0 & 0 & 0 & 0 & 7 & 0 & 0 & 2 & 1 & 0 & 2 & 2 & 0 & 2 & 0 & 3 & 4 & 1 & 0 & 1 & 1 & 0 & $?$ & 0 & $?$ & 0 & 1 & 1 & 0 & 2 & 1 & & 0 & 1 & 0 \\
\hline E. dicranios & 0 & 0 & 3 & 0 & 0 & 0 & 0 & 0 & 0 & 7 & 0 & 0 & 2 & 1 & 2 & 2 & 4 & 2 & 2 & 0 & 3 & 4 & 1 & 0 & 1 & 1. & 0 & $?$ & 0 & $?$ & 0 & 1 & 1 & 0 & & & 0 & 0 & 1 & \\
\hline Dama menana & 0 & 1 & 1 & 0 & 0 & 0 & 0 & 0 & 0 & 2 & 1 & 0 & 0 & 0 & 1 & 0 & 1 & 0 & 1 & 1 & 1 & 3 & 0 & 0 & 2 & 1 & 0 & $?$ & 0 & 1 & 0 & 1 & 1 & 1 & & 0 & & 0 & 2 & 0 \\
\hline Dama nestii & 0 & 1 & 1 & 0 & 0 & 0 & 0 & 0 & 0 & 3 & 2 & 2 & 1 & 0 & 2 & 1 & 1 & 0 & 3 & 0 & 4 & 3 & 0 & 0 & 2 & 1 & 0 & $?$ & 0 & 1 & 0 & 1 & & 1 & & 0 & & 3 & 2 & 0 \\
\hline D. dama clactoniana & 0 & 1 & 0 & 0 & 0 & 0 & 0 & 0 & 0 & 6 & 3 & 2 & 1 & 1 & 2 & 2 & 4 & 1 & 3 & 0 & 4 & 3 & 2 & 0 & 2 & 1 & 0 & $?$ & 0 & 1 & 0 & 1 & 1 & 1 & & & & 3 & 2 & 0 \\
\hline D. dama geiselana & 0 & 1 & 2 & 0 & 0 & 0 & 0 & 0 & 0 & 6 & 3 & 2 & 1 & 0 & 4 & 3 & 6 & 1 & 4 & 0 & 4 & 2 & 2 & 0 & 3 & 1 & 0 & $?$ & 0 & 1 & 1 & 0 & 1 & 1 & & 0 & 0 & 3 & 2 & 0 \\
\hline D. dama dama & 0 & 1 & 1 & 0 & 0 & 0 & 0 & 0 & 0 & 6 & 3 & 2 & 1 & 0 & 3 & 3 & 6 & 0 & 3 & 0 & 4 & 2 & 2 & 0 & 2 & 1 & 0 & 0 & 0 & 1 & 0 & 1 & 1 & 1 & 2 & 0 & & 3 & 2 & 0 \\
\hline D. dama mesopotamica & 0 & 1 & 2 & 0 & 0 & 0 & 0 & 0 & 0 & 6 & 5 & 2 & 2 & 0 & 2 & 2 & 5 & 1 & 2 & 0 & 4 & 1 & 2 & 0 & 2 & 1 & 0 & 0 & 0 & 1 & 0 & 1 & 1 & 1 & 2 & & 1 & 3 & 2 & 0 \\
\hline Axis sp. (Pirro-Nord) & 1 & 0 & 3 & 0 & 0 & 0 & 0 & 0 & 0 & 2 & 2 & 0 & 0 & 0 & 1 & 0 & 1 & 0 & 1 & 1 & 2 & 3 & 0 & 0 & 0 & 1 & 0 & $?$ & 0 & 0 & 0 & 1 & 1 & $?$ & 2 & 1 & 0 & 0 & 0 & 0 \\
\hline Axis axis & 1 & 0 & 3 & 2 & 0 & 0 & 0 & 0 & 0 & 2 & 2 & 0 & 0 & 0 & 1 & 0 & 1 & 0 & 1 & 1 & 2 & 3 & 0 & 0 & 0 & 1 & 0 & 1 & 0 & 0 & 0 & 1 & 1 & 0 & 2 & 1 & 0 & 0 & 0 & 0 \\
\hline Megaloceros verticomis & 0 & 0 & 3 & 3 & 0 & 0 & 0 & 1 & 0 & 6 & 2 & 2 & 2 & 1 & 2 & 2 & 4 & 1 & 3 & 0 & 4 & 5 & 1 & 1 & 1 & 2 & 0 & $?$ & 1 & 1 & 0 & 2 & 0 & b & 2 & 0 & 0 & 1 & 0 & a \\
\hline Megaloceros giganteus & 0 & 0 & 3 & 0 & 1 & & 1 & $?$ & 0 & 6 & 4 & 0 & 2 & 1 & 2 & 3 & 3 & 1 & 4 & 0 & 5 & 6 & 1 & 1 & 1 & 2 & 0 & 1 & 1 & 0 & 1 & 0 & 1 & $\mathrm{~b}$ & 2 & 0 & 0 & 0 & 0 & 2 \\
\hline C. elaphus acoronatus & 2 & 0 & 3 & 3 & 0 & 0 & 0 & 0 & 0 & 4 & 2 & 1 & 2 & 1 & 1 & 0 & 1 & 0 & 1 & 2 & 3 & 4 & 1 & 0 & 1 & 2 & 0 & $?$ & 0 & 0 & 0 & 0 & 0 & 0 & 1. & 0 & & 4 & 1 & 0 \\
\hline C. elaphus hippelaphus & 2 & 0 & 3 & 3 & 0 & 0 & 0 & 0 & 0 & 5 & 2 & 1 & 1 & 1 & 1 & 0 & 1 & 0 & 1 & 2 & 3 & 4 & 1 & 0 & 1 & 2 & 0 & 1 & 0 & 0 & 0 & 1 & 0 & 0 & 1 & 0 & 2 & 4 & 1 & \\
\hline C. nippon nippon & 2 & 1 & 3 & 3 & 0 & 0 & 0 & 0 & 0 & 4 & 2 & 0 & 0 & 1 & 1 & 0 & 1 & 0 & 1 & 2 & 3 & 2 & 1 & 0 & 1 & 1 & 0 & 1 & 0 & 0 & 0 & 1 & 0 & 0 & 1 & 0 & 0 & 4 & 0 & 0 \\
\hline C. nippon hortulorum & 2 & 0 & 3 & 3 & 0 & 0 & 0 & 0 & 0 & 4 & 2 & 0 & 0 & 1 & 1 & 0 & 1 & 0 & 1 & 2 & 3 & 2 & 1 & 0 & 1 & 1 & 0 & 1 & 0 & 0 & 0 & 1 & 0 & 0 & 1 & & & 4 & & 0 \\
\hline
\end{tabular}

Femur

The caput and the great trochanter of each femur were not connected with the diaphyses, while the distal epiphyses had just begun to fuse, indicating an age of less than three years. The location and development of the muscle attachments (cha. 48) on the femur can be used to assign specimens to particular species in adult individuals (Pfeiffer 1999a), but could not be determined exactly here. As in $M$. giganteus and 
Cervus, the diaphysis is rounded in cross section (cha. 50), the fossa intercondylaris is deep, and the distance of the condyles is small (cha. 52). The femur of $M$. verticornis from Bilshausen has a rough, but flattened facies poplitea (cha. 51) by contrast to $M$. giganteus, where the facies poplitea forms a rough, prominent tuberosity. This character is influenced by muscle development and individual age. Consequently, the relatively juvenile age of the individual from Bilshausen reflect the weaker expression of this feature.

\section{Tibia}

The proximal epiphyses are not fused to the diaphyses both of which were broken and subsequently reconstructed. The morphological characters of the proximal and distal ends of the tibia are similar to those of Megaloceros giganteus, thus the internal peak of the tuberculum intercondylare clearly projects beyond the external apex (cha. 53) (compare figure 8 in Pfeiffer 1999c) and, in particular, the development of the distal facets exhibits the derived character states found in Megaloceros verticornis and $M$. giganteus (cha. 56, 57, 58). The dorsal facet that contacts the malleolus lateralis is especially pronounced (cha. 57).

Calcaneus and talus

The calcaneus and talus of the right and left side yielded morphological data. The tuber calcanei was not fused to the corpus calcanei. A small step between the edge of the sustentaculum tali and the articular facet of the calcaneus shaft (Pfeiffer 1999a: fig. 75a, 1a) represents a plesiomorphic character state (cha. 67).

The talus provides more information for the phylogenetic analysis, because all the characters utilised here can be studied in juvenile individuals. The morphology of the talus of Megaloceros verticornis is generally similar to that of $M$. giganteus. An important, derived character is an axially directed depression in the trochlea tali distalis (cha. 72).

\section{Metatarsus III + IV}

Both left and right metatarsals are complete, although their proximal part is reconstructed. The distal epiphyses were beginning to fuse with the diaphyses at the time of death. This ontogenetic stage is consistent with an individual age of two years. Due to the young age of the specimen the diaphyses of MT III + IV are not connected distally. Character states for the distal MT III + IV are similar to those for Megaloceros giganteus (Pfeiffer 1999c: fig. 9).

\section{Phalanges}

All phalanges of $M$. verticornis from Bilshausen could be studied. The epiphyses of the first and second phalanges, which fuse at the beginning of the second year in deer, are all completely fused

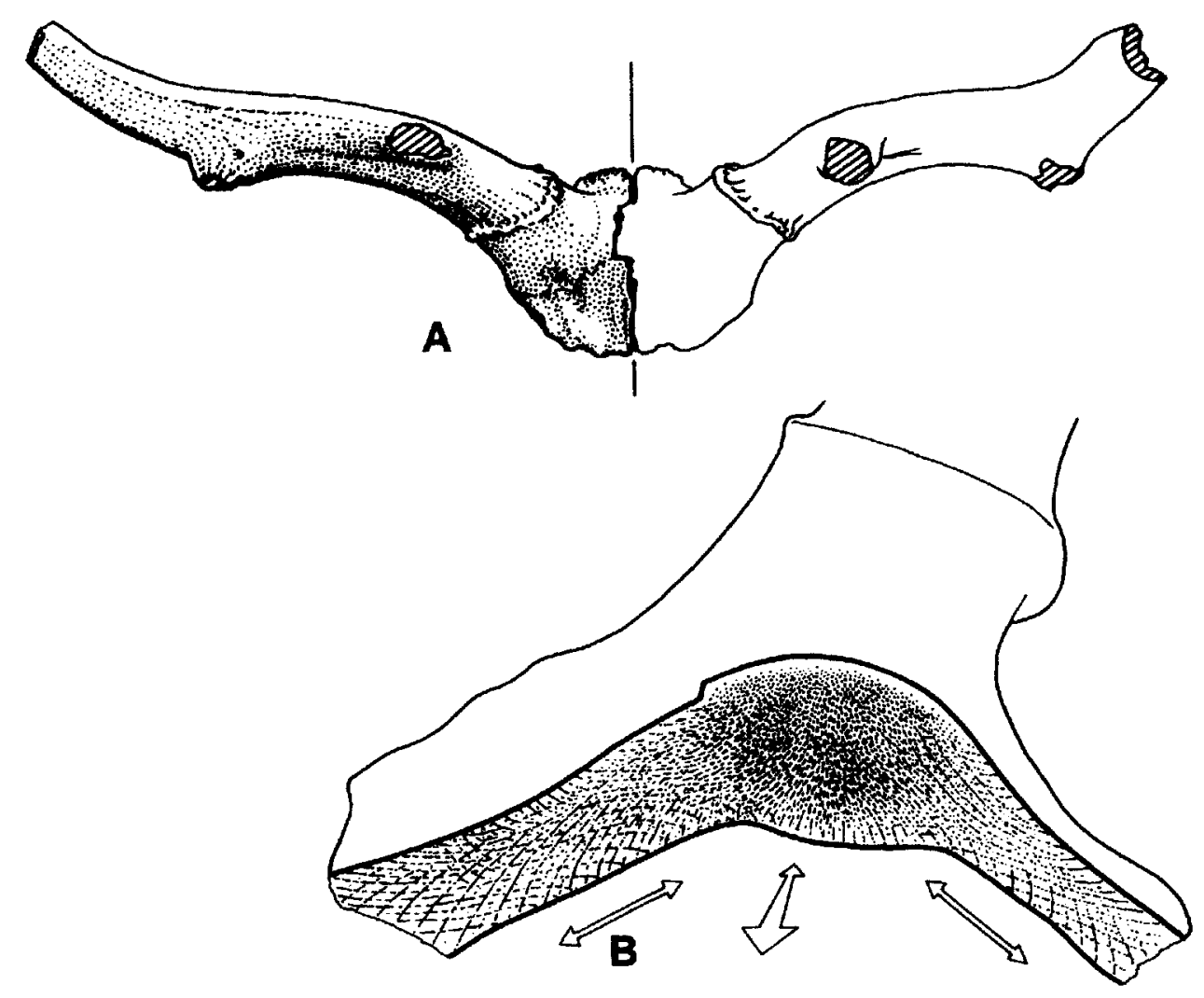

Fig. 4. A. Fragments of the skull and antler of an adult male of Megaloceros verticornis from Süßenborn. B. The frontal bones are particularly thick. The strategic alignment and distribution of trabecular bone is primarily related to the direction of normal loading. This orientation and the thickening of the frontals was also observed in the specimen from Süßenborn (IQW Süß 7117). 
in the Bilshausen specimen. The first and second phalanges also have robust diaphyses and exhibit most morphological characters of Megaloceros (Pfeiffer 1999c: fig. 10).

\section{Discussion and results}

Many skeletal characters are influenced by ontogenetic growth patterns, sexual dimorphism, and functional adaptation, and may show high variability within a cervid species (Pfeiffer 1999a). An important problem is that characters of antlers and skulls of juvenile individuals of one species with a complex antler morphology can appear similar to characters of antlers of adult stages of other species. As an example Cervus elaphus, and $C$. nippon e.g. can have a three-point antler stage in juvenile individuals that is comparable to the antler stage of an adult of Axis axis (Table 2, cha. 92). In most species of deer the sutures of the skull are still almost visible in adult individuals, but are nearly completely erased in adult megalocerines (cha. 111). Juvenile megalocerines do not have pachygnathous mandibles as in most other species of deer, but they can be extremely pachygnathous in old individuals (Table 2, cha. 122). All antler- and skull characters in the data matrix (cha. 92-111, 122) are influenced by ontogenetic growth patterns. It is therefore extremely important to specify the character development in adult individuals of all species in the phylogeny reconstruction.

Megaloceros verticornis from Süßenborn and Voigtstedt (Kahlke 1956, 1960, 1965, 1969) shows, that palmation clearly increases in older individuals. The enormous weight of these antlers resulted in special adaptations in cranial morphology. Bone material had to be added at the linea nucha, and this became a nuchal crest in older stags. Adult male deer with wide spread antlers therefore show an extreme thickening of the frontal bones between the pedicles. The strategic alignment and distribution of trabecular bone is primarily related to the principal direction of normal loading. This orientation and thickening of the frontals was observed in an adult male of Megaloceros verticornis from Süßenborn (Fig. 4). Similarly, an increase in antler development in Alces latifrons is related to the thickening of the frontals (Pfeiffer 1999b). Unfortunately, in the palaeontological literature the classification of the alcini is mainly based on adaptive characters (Azzaroli 1953, 1983, 1985, 1994). Breda (2001) discussed the skull chafac- ters of the alcini in more detail noting the structural adaptations made necessary by an increase of antler- and bodysize. The development of a nuchal crest, for example, could be observed in many cervid species with strong antlers, including E. tegulensis, Cervus elaphus, Dama dama, $M$. giganteus, and Alces latifrons. Such independently acquired characters seem to be highly homoplastic in cervids, and are difficult to use for determining phylogenetic relationships. This observation concords with the results of Scott \& Janis (1993).

Results of the computer-aided cladistic analysis

The parsimony analysis (MP) using PAUP 4.0 resulted in a single most parsimonious tree (length 579, CI: 0.578). The robustness of the phylogeny was assessed using the bootstrap method (Fel-

\section{Bootstrap}

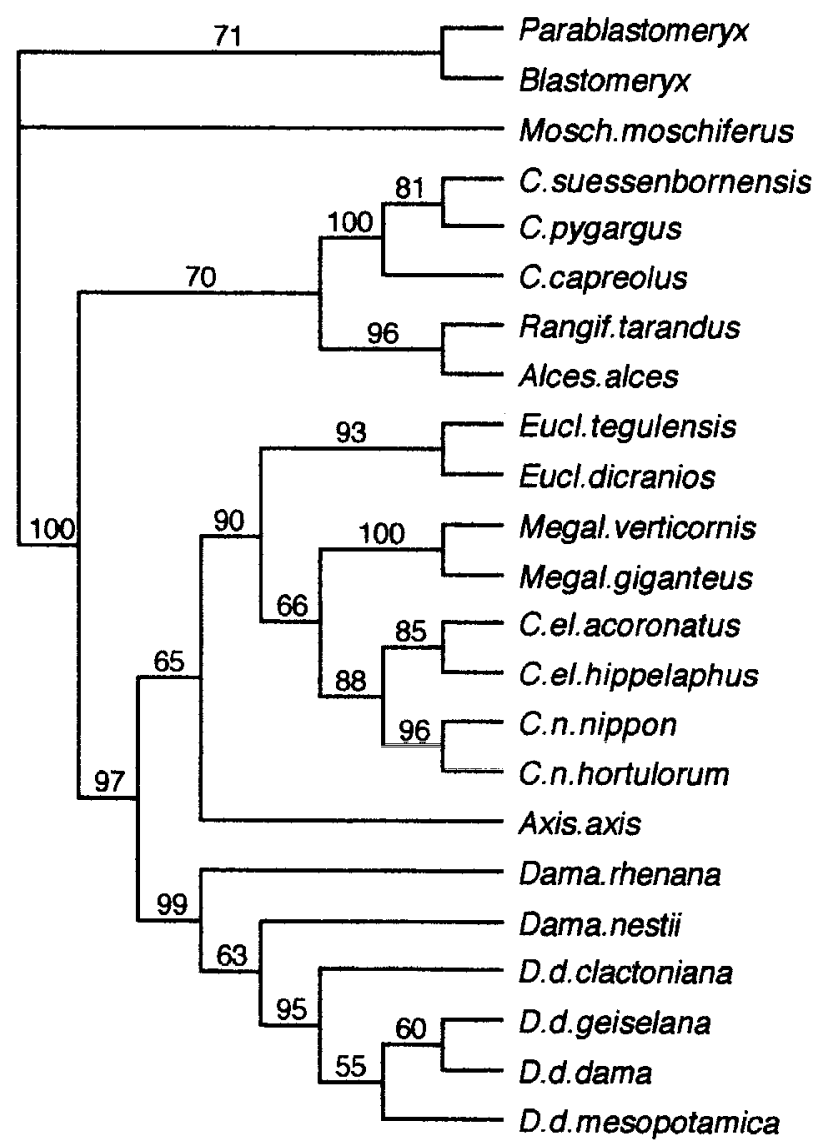

Fig. 5. Majority rule consensus tree, after 1000 bootstrap resamplings, describing the evolutionary relationships of 20 fossil and Recent cervids, and 3 outgroup artiodactyls as deduced from 122 skeletal characters. At each node the bootstrap percentage (BP) is given. One single most parsimonious tree (MP) was found with the same topology (length $=579, \mathrm{CI}=0.5872$ ).

The monophyly of Megaloceros verticornis and $M$. giganteus is well suppofted $(\mathbf{D P}=100)$. 
senstein 1985), and the maximum likelihood method (ML). The majority-rule consensus tree after 1000 bootstrap resamplings, describing the evolutionary relationships between 20 fossil and Recent cervids, and three outgroup artiodactyls based on a comparison of 122 skeletal characters obtain has the same topology as the MP tree (Fig. 5). The tree computed by the (ML) method differs only in the position of Axis, which is located in a clade with Dama in the ML analysis. At each node, the bootstrap percentage (BP) is given above the branch.

The family Cervidae is defined by 32 characters at the basal node of the MP tree, and there is strong support for cervid monophyly from the bootstrap values $(B P=100)$. This result agrees with the phylogenetic analysis computed from molecular data (Cronin et al. 1996, Douzery \& Randi 1997, Randi et al. 1998). The subfamilies, Odocoileinae and Cervinae, occurred as monophyletic groups within the Cervidae. Fourteen characters $(\mathrm{BP}=70)$ define the telemetacarpal odocoileine deer, and 19 characters $(B P=97)$ define the plesiometacarpal Cervinae.

Within the Odocoileinae the genus Capreolus is considerably differentiated from the other taxa, with 19 characters defining its branch on the MP tree $(\mathrm{BP}=100)$. Capreolus suessenbornensis $(=C$. cusanoides Kahlke 2001) from the late Lower Pleistocene of Untermaßfeld and the Middle Pleistocene of Germany (Mosbach, Miesenheim, Süßenborn) is nearly identical to its Recent relatives $C$. capreolus and $C$. pygargus in its skeletal characters. Three characters define the position of $C$. capreolus and the clade of $C$. pygargus and $C$. suessenbornensis, while one character defines $C$. suessenbornensis. These taxa differ only in body size and antler development, the diagnostic antler characters of $C$. cusanoides described by Kahlke (2001) can be included in the range of antler variation exhibited by $C$. suessenbornensis from Mosbach. Therefore $C . c u-$ sanoides is assumed here to be a junior synonym of $C$. suessenbornensis.

Table 4

Metric data for preserved teeth and postcranial skeletal elements of Megaloceros verticornis from Bilshausen (measurements after v. d. Driesch 1976).

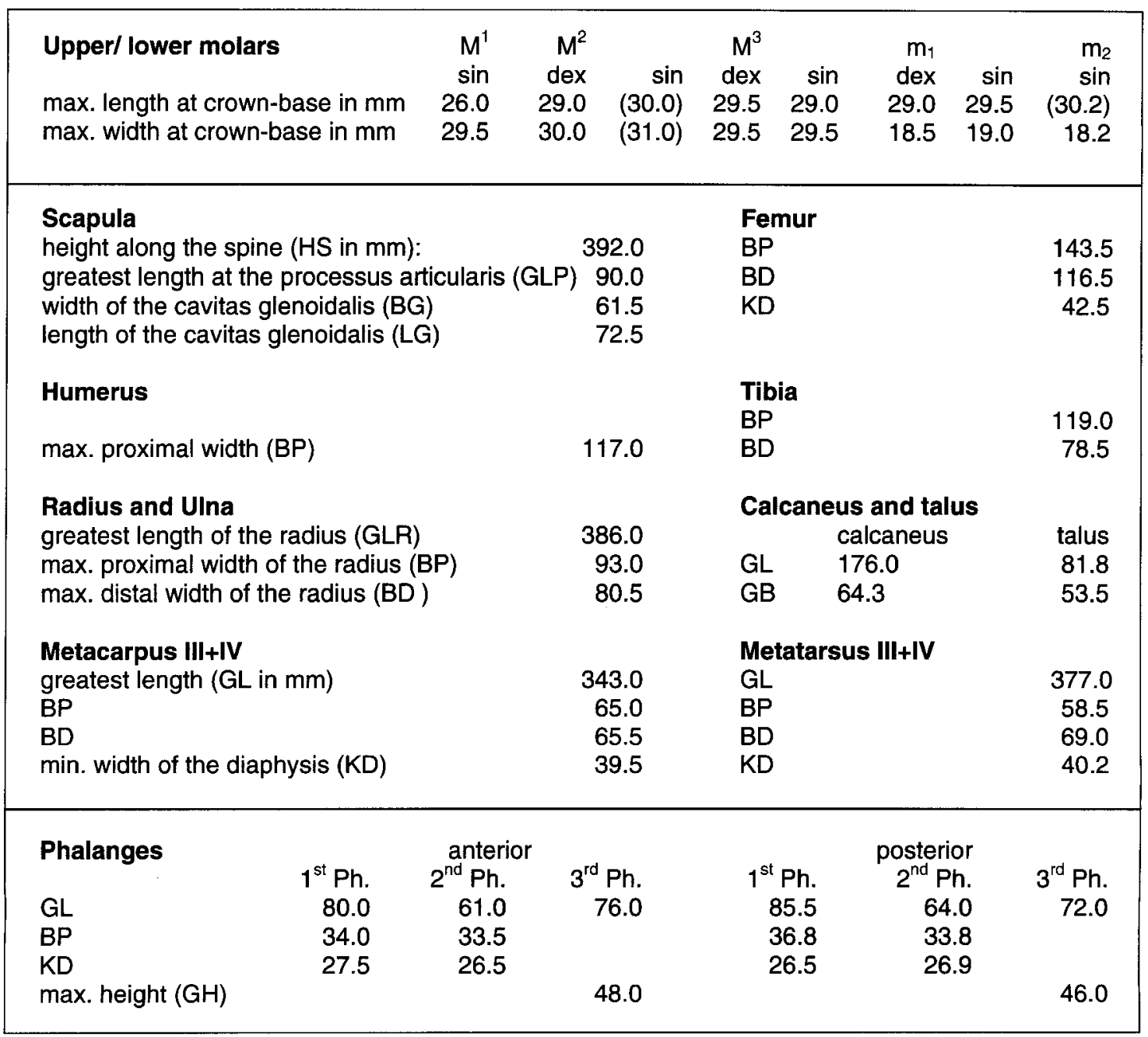


The association of Rangifer in a clade with Alces $(\mathrm{BP}=96)$ is in contrast to the results of a study by (Cronin et al. 1996) based on K-casein DNA-data. Both genera, for example, share a derived morphology of the lower $\mathrm{p}_{4}$, and the clade is well supported by 25 characters in the analysis reported here. However, Rangifer taran$d u s$ is considerably differentiated from Alces alces: 24 characters define $R$. tarandus, while 20 characters support $A$. alces.

The plesiometacarpal deer split into a Damalineage, defined by 26 characters $(B P=99)$, and a clade consisting of the fossil genera Eucladoceros, Megaloceros, Cervus (fossil and Recent species), and the Recent species $A x i s$, defined by 12 characters. The bootstrap value is low for this internal node $(\mathrm{BP}=65, \mathrm{DI}=+2)$.

As demonstrated by Pfeiffer (1999a) Axis shares many postcranial characters with the genus Cervus, and on the other hand, also with Dama, but locating Axis in a single clade with Cervus, Eucladoceros, and Megaloceros, involves 12 additional steps (by contrast to the 14 additional steps, necessary to unit Axis in a clade with Dama), and this is reflected in the relatively low consistency index of the data set (CI: 0.578).

Tree topology within the Dama-lineage reflects the evolution of this genus from the PlioPleistocene to the Holocene. In the Plio-Pleistocene Dama rhenana had evolved a three-point antler stage, followed in the Lower Pleistocene by Dama nestii, with a 4-point antler without palmation, and then, in the Middle Pleistocene to Recent times, of fallow deer with palmated antlers. Considering the rich skeletal material of the Dama-lineage it can be observed that more than one character state may occur in a single species for a particular character. Quite often, both apomorphic and plesiomorphic character states, may occur in the same species as a polymorphic character. Such apparently variable characters can yield important phylogenetic information. Within the Dama-lineage it was possible to follow the shift from a plesiomorphic character state that occurs with a high frequency in Dama rhenana, which lies at the basis of the lineage, to an apomorphic character state in the stratigraphically younger Dama-species (Pfeiffer 1999a, in press).

The clade including Eucladoceros, Megaloceros and Cervus is defined by 23 characters $(\mathrm{BP}=90)$. Comparing this data in detail, the characters 2, 4, 5, 6 and 9 (concerning cervical vertebrae), $76,77,78,82,83,84,85$, (concerning $1^{\text {st }}$ and $2^{\text {nd }}$ phalanges), 95, 96, (concerning an- tlers), and 105, 107, (concerning the skull) all support this node. Except the Japanese sika deer C. nippon nippon, all taxa in this clade are robust cervids, with large and heavy antlers. The morphology of the cervical vertebrae is extremely influenced by the morphology and weight of the antlers, as demonstrated by Lengsfeld (1975) and Pfeiffer (1999a), and the phalanges need special adaptations to support the body weight (Pfeiffer 1999a, b). Therefore it should be taken into account that the high bootstrap value for this clade may be the result of homoplasy.

The clade including Megaloceros and Cervus is defined by 17 characters $(B P=66)$. In particular, the shared morphology of the tuberculum supraglenoidale of the scapula (cha. 14), the similar morphology of radius and ulna (cha. 26, 28, $29,35)$, and the morphology of the upper $\mathbf{M}^{3}$ (cha. 118) was not observed in other plesiometacarpal deer genera, and seems to support their relationship.

As in other phylogeny reconstructions computed from molecular data (Cronin et al. 1996, Douzery \& Randi 1997, Randi et al. 1998) the Cervus clade including red deer and sika deer is well supported (17 characters, $\mathrm{BP}=88$ ). Within Cervus, the East-Asian sika deer Cervus nippon $(B P=96)$ appears to have been distinct from the European Cervus elaphus since the Pliocene $(\mathrm{BP}=85)$. A large group of consistent characters are present in Cervus, and appear to have persisted for a long time span. Moreover a study of bone material of Pseudaxis grayi Zdansky 1925 from Lower Pleistocene localities of the Shansi Basin in China shows evidence that $P$. grayi is an early, true member of Cervus nippon (Pfeiffer, in prep.).

Douzery \& Randi (1997) calibrated divergence times on the basis of molecular data. In their study divergences of 3.3-7.1 Myr within the genus Cervus are postulated, and 0.4-2.5 Myr within Cervus elaphus.

Cervus elaphus was first identified in Europe from early Middle Pleistocene localities in Great Britain (Cromer Forest-bed, Lister 1996) and Germany (Voigtstedt, Süßenborn, Mosbach, Kahlke, 1956, 1960, 1965, Koenigswald \& Heinrich 1999, Pfeiffer 1999a) represented by the fossil subspecies $C$. elaphus acoronatus. The antlers of Cervus elaphus acoronatus (= Cervus acoronatus Beninde 1937) from Mosbach always lack a crown in the distal part, although this species exhibits a nearly identical postcranial character set to that of extant individuals of Cervus elaphus hippelaphus. Three characters define C. $e$. 
acoronatus, while five define the extant $C$. elaphus hippelaphus.

The monophyly of Megaloceros verticornis and $M$. giganteus is well supported $(\mathrm{PB}=100,27$ steps), and these species share 15 postcranial character states do not occur in other plesiometacarpal deer species: the cranial facet of the $3^{\text {rd }}$ and $4^{\text {th }}$ cervical vertebrae (cha. 7), the shape of the cavitas glenoidalis of the scapula (cha. 12), the rounded scores in the fossa radialis of the humerus (cha. 21), the axially especially deep fossa olecrani (cha. 24), the development of the cranial facet of the radius (cha. 29,30), character states of the distal tibia (cha. 56, 58), development of the proximal end of MC III + IV (cha. 61,62 ), and the astragalus (cha. 72, 73). These characters seem to be diagnostic for giant deer, and support a close relationship between the two giant deer species which are combined in a single genus, Megaloceros, here.

Dama and Megaloceros clearly represent separate lineages within the main clade of plesiometacarpal deer, because they share relatively few postcranial skeletal character states. Moreover the topology of the MP tree supports the idea that the occurrence of palmate antlers in both genera must be the result of homoplasy.

\section{Acknowledgements}

I wish to thank Prof. Dr. D. Meischner and Prof. Dr. J. Schneider (Göttingen) for permission to study the giant deer from Bilshausen. Their kind support during my visits to Göttingen was of great help. Fig. 1 was provided by Prof. Meischner. I wish to thank Prof. Dr. H.-D. Kahlke (Weimar), Prof. Dr. W. v. Koenigswald (Bonn), Dr. G. Böhme, and Prof. Dr. H.-P. Schultze (Berlin) for kindly discussing issues covered in this study. I am very grateful to various scientists and curators who allowed me to study material in their care: Dr. M. Ade, Dr. W.-D. Heinrich (Berlin), Prof. Dr. A. v. d. Driesch (Munich), Dr. W. Eckloff (Lübeck), Dr. A. Feiler (Dresden), Dr. D. Heinrich (Kiel), Dr. R. Hutterer (Bonn), Dr. H. Jung (Mainz), PD Dr. R.-D. Kahlke (Weimar), Prof. Dr. D. Mania, (Jena), Dr. U. Scheer (Essen), Dr. G. Gruber (Darmstadt), Dr. G. Storch, Dr. G. Plodowski, Prof. Dr. F. Schrenck (Frankfurt), Dr. R. Ziegler, Dr. E. Heizmann (Stuttgart), Mr. E. Zenker (Wiesbaden), Dr. L. Abbazzi, Prof. Dr. D. Torre, Dr. L. Rook (Florence), Dr. L. Capasso Babato, Prof. Dr. C. Petronio (Rome), Prof. Dr. B. Engesser (Basel), Prof. Dr. C. Guerin, Dr. M. Fauré (Lyon), Dr. S. Stuenes (Uppsala), Dr. A. Sutcliffe, Dr. J. Hooker, Dr. A. Currant (London), Prof. Dr. E. Tchernov, Dr. R. Rabinovich (Jerusalem), Dr. R. Tedford (New York), Dr. J. d. Vos (Leiden). I am grateful to Dr. J. Dunlop, and Dr. D. Unwin (Berlin) for help in correcting the English text, and to Mr. J.-P. Mendau for producing Figs. 2 and 4, Mrs. E. Siebert (Berlin) for amending Fig. 1. I thank Prof. Dr. G. Arratia, Dr. D. Unwin, Prof. Dr. W. v. Koenigswald, and Dr. R. Ziegler for detailed reviews. This investigation was made possible by financial support from the Deutsche Forschungsgemeinschaft (DFG).

\section{References}

Alessandri, G. de 1903. Sopra alcuni avanzi di cervidi pliocenici del Piemonte. - Atti della R. Academia della Science Torino.

Azzaroli, A. 1953. The deer of the Weybourne Crag and Forest bed of Norfolk. - Bulletin of the British Museum (Natural History), Geology 2: 3-96.

- 1983. On the Quaternary and Recent Cervid Genera Alces, Cervalces, Libralces. - Bolletino Societa Paleontologia Italiana 20: $147-154$.

- 1985. Taxonomy of Quaternary Alcini (Cervidae, Mammalia). - Acta Zoologica Fennica 170: 179--180.

- 1994. Forest bed elks and giant deer revisited. - Zoological Journal of the Linnean Society 112: 119-133.

Azzaroli, A. \& Mazza, P. 1992. On the possible origin of the Giant Deer genus Megaceroides. - Atti Accademia Lincei, Rendiconti Scienze Fisiche e Naturali $\left(9^{\text {th }}\right.$ series) 3: 23-32.

Belgrand, E. 1869. Histoire generale de Paris. La Seine I: Basin parisien aux antehistoriques 3: 13. La Seine I. Basin parisien, planch. paléont. S.13, Taf. $18 \mathrm{ff}$.

Beninde, J. 1937. Zur Naturgeschichte des Rothirsches. Monographien der Wildsäugetiere 4: 1-223.

Bittmann, F. \& Müller, H. 1996. The Kärlich Interglacial site and its correlation with the Bilshausen sequence. In Turner, C. (ed.). The early Middle Pleistocene in Europe: 187-193. Balkema, Rotterdam.

Bogaard, C. van den, Bogaard, P. van den \& Schmincke, H.U. 1989. Quartärgeologisch-tephrostratigraphische Neuaufnahme und Interpretation des Pleistozänprofils Kärlich, F.R.G. - Eiszeitalter und Gegenwart 39: 62-86.

Breda. M. 2001. The holotype of Cervalces gallicus (Azzaroli, 1952) from Senéze (Haute-Loire, France) with nomenclatural implications and taxonomical-phylogenetic accounts. - Rivista Italiana di Paleontologia e Stratigrafia 107(3): 439-449.

Brookes, J. 1828. A Catalogue of the Anatomical and Zoological Museum Joseph Brookes, Esp., part 1: 61.

Cronin, M. A., Stuart, R., Pierson, B. J. \& Patton, J. C. 1996. Kcasein gene phylogeny of higher ruminants (Pecora, Artiodactyla). - Molecular Phylogenetic Evolution 6: 295-311.

Dawkins, W. B. 1868. On a new species of fossil Deer from Clacton. - Quarterly Journal of the Geological Society of London 24: 511-516.

Douzery, E. \& Randi, E. 1997. The Mitochondrial Control Region of Cervidae: Evolutionary Patterns and Phylogenetic Content. - Society for Molecular Biology and Evolution 14 (11): 1154-1166.

Driesch, von den, A. 1976. Das Vermessen von Tierknochen aus vor- und frühgeschichtlichen Siedlungen. - Inst. Paläoanatomie, Domestikationsforschung und Geschichte der Tiermedizin Universität München: 1-114.

Felsenstein, J. 1985. Confidence limits on phylogenies: an approach using the bootstrap. - Evolution 39: 783-791.

Freudenberg, W. 1914. Die Säugetiere des älteren Quartärs von Mitteleuropa. - Geologische und Paläontologische Abhandlungen 12 (4/5): 455-670.

Geist, V. 1971. The relation of Social Evolution and Dispersal in ungulates during the Pleistocene, with Emphasis on the Old World Deer and the genus Bison. - Quaternary Research 1 (3): 283-315.

- 1987. On speciation in Ice Age mammals, with special reference to cervids and caprids. - Canadian Journal of Zoology 65: 1067-1084.

Goldfuß, G. A. 1820. Handbuch der Zoologie 2: 20: 374

Gould, S. J. 1974. The origin and function of bizarre structures: antler size and skull size in the 'Irish elk', Megaloceros giganteus. - Evolution 28: 191-220.

Groves, C. P. \& Grubb, P. 1987. Relationships of living deer. In Wemmer, C. M. (ed.). Biology and management of the Cervidae, pp. 21-59, Smithsonian Institution Press, Washington. D.C. 
Grüger, E., Jordan, H., Meischner, D. \& Schlie, P. 1994. Mittelpleistozäne Warmzeiten in Göttingen, Bohrungen Ottostraße und Akazienweg. - Geologisches Jahrbuch A 134: $167-210$.

Habermehl, K. H. 1961. Die Altersbestimmung bei Haustieren, Pelztieren und beim jagdbaren Wild. - Parey, Hamburg und Berlin.

Harmer, F. 1889. On a specimen of Cervus belgrandi (Lartet) (C. verticornis Dawk.) from the Forest-Bed of East Anglia. -Transactions of the Zoological Society 15: London.

Heintz, E. \& Poplin, F. 1981. Alces carnutorum (Laugel, 1862) du Pléistocène de Saint-Prest (France). Systématique et évolution des Alcinés (Cervidae, Mammalia). Quartärpaläontologie 4: 105-122.

Joleaud, L. 1914. Cervus (Megaceroides) algericus Leydekker, 1890. - Recueil des Notices et Mémoires de la Société Archéologique du Dép. De Constantine 5 (5): 1-67.

Kahlke, H.-D. 1956. Die Cervidenreste aus den altpleistozänen Ilmkiesen von Süßenborn bei Weimar. - Bd. 1: $62 \mathrm{~S}$., Akademie-Verlag, Berlin.

- 1960. Die Cervidenreste aus den altpleistozänen Sanden von Mosbach (Biebrich-Wiesbaden). - Abhandlungen der Deutschen Akademie der Wissenschaften, Klasse für Chemie, Geologie und Biologie 7: 1-75.

- 1965. Die Cervidenreste aus den Tonen von Voigtstedt. Paläontologische Abhandlungen A 2 (2/3): 379-425.

- 1969. Die Cerviden-Reste aus den Kiesen von Süßenborn bei Weimar. - Paläontologische Abhandlungen A 3 (3/4): $547-610$

- 2001. Neufunde von Cerviden-Resten aus dem Unterpleistozän von Untermaßfeld. - Monographien des RömischGermanischen Zentralmuseums Mainz 40 (2): 461-482.

Kahlke, R.-D. 1994. Die Entstehungs-, Entwicklungs- und Verbreitungsgeschichte des oberpleistozänen Mammuthus - Coelodonta - Faunenkomplexes in Eurasien (Großsäuger). - Abhandlungen der Senckenbergischen naturforschenden Gesellschaft 546: 1-164.

Kishino, H. \& Hasegawa, M. 1989. Evaluation of the maximum likelihood estimate of the evolutionary tree topologies from DNA sequence data, and the branching order in Hominoides. - Journal of Molecular Evolution 29 $170-179$.

Koenigswald, W. v. \& Heinrich, W.-D. 1999. Mittelpleistozäne Säugetierfaunen aus Mitteleuropa - der Versuch einer biostratigraphischen Zuordnung.- Kaupia 9: 53-112.

Laugel, A. 1862. La faune de Saint-Prest, près Chartres (Eure-et-Loir). - Bulletin Societé Géolique de France 2. Ser. 19 (1861-1862): 709-718.

Lengsfeld, K.-P. 1975. Über den formenden Einfluß des Cervidengeweihs auf Hinterhaupt und erste Halswirbel. Dissertation Institut für Haustierkunde, Universität Kiel.

Lister, A. M. 1984. Evolutionary and ecological origins of British deer. - Proceedings of the Royal Society of Edinburgh 82B: 205-229.

- 1987. Megaloceros Brookes, 1828 (Mammalia, Artiodactyla): proposed emendation of the original spelling. Bulletin of Zoological Nomenclature 44 (4): 255-256.

- 1993. The stratigraphical significance of deer species in the Cromer Forest-bed Formation. - Journal of Quaternary Science 8: $95-108$.

- 1994. The evolution of giant deer, Megaloceros giganteus (Blumenbach). - Zoological Journal of the Linnean Society 112: $65-100$.

- 1996. The stratigraphical interpretation of large mammal remains from the Cromer Forest-bed Formation. In Turner, C. (ed.). The early Middle Pleistocene in Europe, pp. 25-44, Balkema, Rotterdam.

Lydekker, R. 1890. On a Cervine Jaw from Algeria. - Proceedings of the Zoological Society of London for the year 1890: $602-604$.

Meischner, D. 1995. Black Shales Models. - III EPA Workshop, Dotternhausen.
Meischner, D. \& Schneider, J. 1967. 500000 Jahre alter Steppenhirsch gefunden. - Deutsche Jägerzeitung 22: $870-872$.

Moullade, E. 1886. Note sur une nouvelle espèce de daim fossile. - Mém. Soc. Agr. Sci. H.te Loire 4: 304-306.

Müller, H. 1965. Die pollenanalytische Neubearbeitung des Interglazial-Profils von Bilshausen (Unter-Eichsfeld). Geologisches Jahrbuch 83: 327-352.

Newton, E. T. 1882. The Vertebrata of the Forest bed Series of Norfolk and Suffolk. - Memoirs of the Geological Survey of English. Wales. HMSO, London.

Owen, R. 1842. Report on British Fossil Mammalia.- Reports of the British Association, p. 237.

Pfeiffer, T. 1999a. Die Stellung von Dama (Cervidae, Mammalia) im System plesiometacarpaler Hirsche des Pleistozäns - Phylogenetische Rekonstruktion - Metrische Analyse. - Courier Forschungsinstitut Senckenberg 211: $1-218$.

- 1999b. Alces latifrons (Johnson, 1874) (Cervidae, Mammalia) aus den jungpleistozänen Kiesen der Oberrheinebene. - Neues Jahrbuch für Paläontologie, Abhandlungen 211 (3): 291-327.

- 1999c. The Morphological Distinction of Limb Bones of Alces latifrons (Johnson, 1874) and Megaloceros giganteus (Blumenbach, 1799). - Kaupia, Darmstädter Beiträge zur Naturgeschichte 9: 113-126.

- in press. The position of Dama (Cervidae, Mammalia) in the system of fossil and living deer from Europe - Phylogenetic analysis based on skeletal characters. - Quaternaire.

Pomel, A. 1892. Sur deux ruminants de l'epoque n'lithique en Algerie: Cervus pachygenis et Antilope maupasi. C.R. Acad. Sc. Paris, CXV: 213.

Portis, A. 1920. Elenco delle specie di cervicorni fossili in Roma e attorno a Roma. - Bolletino della Società Geologica Italiana 39: 132-139.

Randi, E., Mucci, N., Pierpaoli, M. \& Douzery, E. 1998. New phylogenetic perspectives on the Cervidae (Artiodactyla) are provided by the mitochondrial cytochrome $b$ gene. Proceedings of the Royal Society of London B 265: 793-801.

Rieck, W. 1983. Damwildalter-Merkblatt. In Schalenwildausschuß des Deutschen Jagdschutz-Verbandes e.V. (ed.), 3. Aufl. S. 1-7, Hoffmann, Mainz.

Schmidt, H. 1930. Ein Skelett von Alces latifrons aus der Gegend von Göttingen. - Paläontologische Zeitschrift 12: 135.

- 1934. Ein Skelett vom Riesenelch. - Forschungen und Fortschritte 10 (15): 198-199.

Scott, K. M. \& Janis, C. M. 1993. Relationships of the Ruminantia (Artiodactyla) and an analysis of the characters used in ruminant taxonomy. In Szalay, F. S., Novacek, M. J. \& Mc Kenna. M. C. (eds). Mammal Phylogeny: Placentals, pp. 282-302, Springer, New York.

Soergel, W. 1927. Cervus megaceros mosbachensis n. sp. und die Stammesgeschichte der Riesenhirsche. - Abhandlungen der Senckenbergischen Naturforschenden Gesellschaft 39: 375-505.

Strimmer, K. \& von Haeseler, A. 1996. Quartet puzzling: a quartet maximum-likelihood method for reconstructiing tree topologies.- Molecular Biology and Evolution 13: 964-969.

Swofford, D. L. 1998. "PAUP*. Phylogenetic Analysis Using Parsimony (*and other methods)." Version 4. Sinauer Associates, Sunderland, MA

Thenius, E. 1958. Geweihjugendstadien des eiszeitlichen Riesenhirsches, Megaceros giganteus (Blum.) und ihre phylogenetische Bedeutung. - Acta Zoologica Cracoviensia 2 (30): 707-721.

Zdansky, O. 1925. Fossile Hirsche Chinas. - Palaeontologia Sinica C 2 (3): 1-94. 